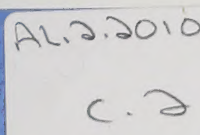
200.8

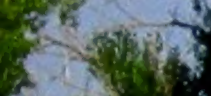

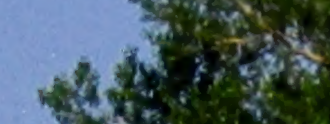

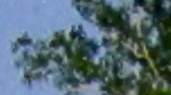

10,5

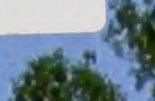

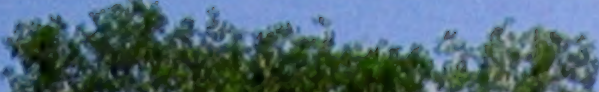

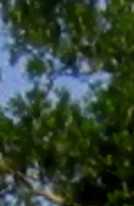

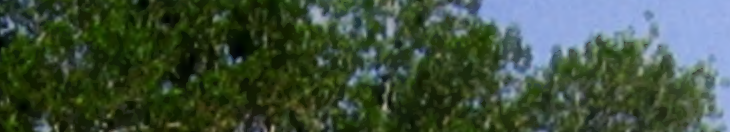

ato sting

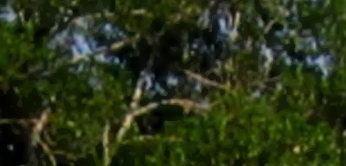

tista

ing

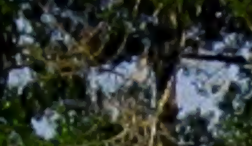

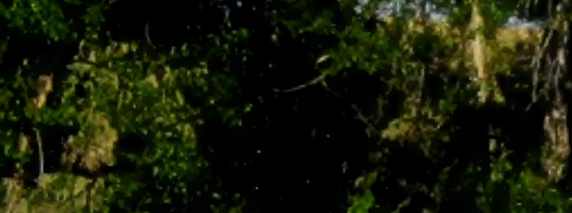

rats.

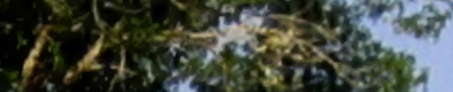

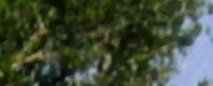

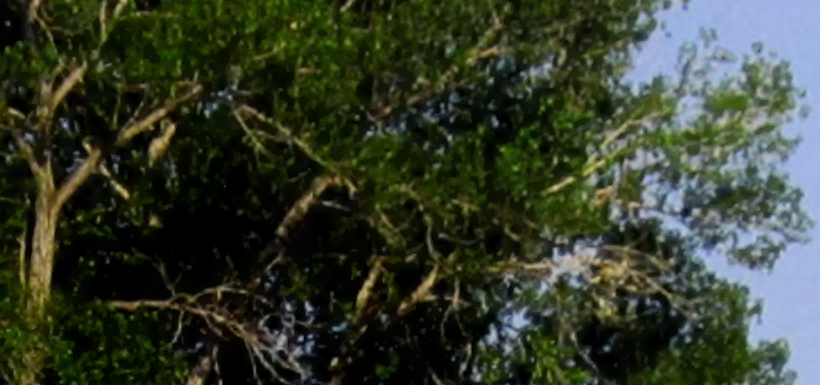

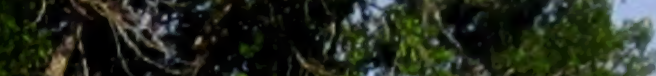

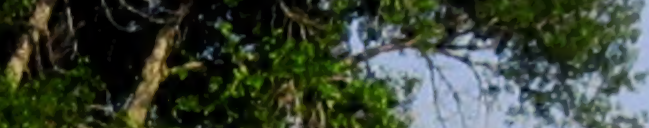

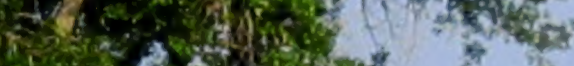

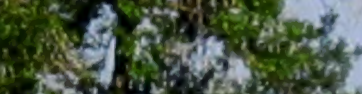

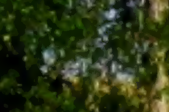


Digitized by the Internet Archive in 2016 


\section{Using Aerial Videography to Assess Riparian Areas in Southern Alberta: A Pilot Study}

Prepared by:

Alberta Environment

Southern Region

Calgary, Alberta 


\section{ISBN: 978-0-7785-8979-2 (Printed Edition) \\ ISBN: 978-0-7785-8980-8 (On-line Edition)}

Website: www.environment.alberta.ca

\section{Disclaimer}

The contents of this document have been prepared with funds from Alberta Environment but do not necessarily reflect the Ministry's views or policies. Any mention of trade names or commercial products does not constitute an endorsement or recommendation for use.

Any comments, questions or suggestions on the content of this document may be directed to:

Regional Environmental Management

Alberta Environment

3rd Floor, Deerfoot Square

2938 - 11th Street N.E.

Calgary, Alberta T2E 7L7

Ph: (403) 297-7602

FAX: (403) 297-6069

\section{Additional Print Copies}

Additional print copies of this document are available from:

Information Centre

Alberta Environment

Main Floor, Oxbridge Place

9820-106 Street

Edmonton, Alberta T5K $2 \mathrm{J6}$

Ph: (780) 427-2700

Fx: (780) 422-4086

Outside of Edmonton dial 310-0000 for toll-free connection

Email: env.infocent@gov.ab.ca

This report can be cited as: Alberta Environment. 2010. Using Aerial Videography to Assess Riparian Areas in Southern Alberta: A Pilot Study. Alberta Environment, Calgary. 40 pp.

Copyright in this publication, regardless of format, belongs to Her Majesty the Queen in right of the Province of Alberta. Reproduction of this publication, in whole or in part, regardless of purpose, requires the prior written permission of Alberta Environment.

(c) Her Majesty the Queen in right of the Province of Alberta, 2010. 


\section{Executive Summary}

Spatially encoded video, including aerial videography, is used widely in the monitoring of linear environmental features, such as road and utility corridors. Recently, it has been used in Alberta for assessing the condition (health) of riparian areas adjacent to lakes and rivers, but its effectiveness for this purpose has not been fully evaluated. The objective of this study was to evaluate aerial videography as a method for assessing the condition of riparian areas along rivers and streams in southern Alberta. In 2006, a variety of reaches was selected across a range of geographical conditions, from small streams in grassland settings to large watercourses with forested shorelines. The riparian strips adjacent to these watercourses were filmed from a helicopter using a video camera connected to a GPS. A scoring method was developed that included several parameters related to riparian condition and which could be seen on the aerial video imagery. The scores were mapped, and the results independently evaluated by a resource inventory specialist. The imagery was transferred to DVD, and together with the scoring results, was distributed to local watershed groups.

About $750 \mathrm{~km}$ of riparian area along 18 separate reaches were flown over a period of two days. In general, the quality of the imagery was adequate for identifying ground details such as bare ground, bank armouring and evidence of cattle grazing. Finer details, such as signs of tree recruitment and the density and height of forbs and grasses, were more difficult to see. Several factors affected video quality, including light conditions, and the altitude, speed, and position of the helicopter. In some sections, dense tree cover made it hard to see the condition of the ground, while in others stream sinuosity made maintaining close contact with the stream difficult. The use of GPS and GIS technology facilitated the mapping process.

Overall, aerial videography shows promise for assessing the condition of riparian areas along rivers and streams in southern Alberta. The method provides a relatively rapid, low-cost way of permanently recording land-use and environmental conditions on the relatively narrow strips of land that make up riparian areas in this part of the province. The imagery collected can later be interpreted and supplemented with ground-based data. Refinements to data capture, scoring method, and a comparison of results from this project with ground-based studies should be considered before undertaking further work of this kind. Newer technologies are now available that enable automated geo-referencing of video images and provide a range of postflight processing and viewing options. 


\section{Project Coordination and Report Writing:}

Jan Simonson, Alberta Environment

\section{Acknowledgements:}

Project Sponsors:

Heather Sinton, Alberta Environment

Land Monitoring Team, Alberta Environment

Budget Administration and Contracts:

Gary Byrtus, Alberta Environment

Denise Auriat, Alberta Environment

Videography and Post-flight Processing:

George Walker, Walker Environmental, Cherry Grove, AB

Flight Coordination, Oldman River Basin:

Brad Taylor, Alberta Conservation Association

GIS Processing and Maps:

Angela Braun, Alberta Sustainable Resource Development

Riparian Scoring Method Consultation \& Advice:

Norine Ambrose, Cows and Fish

Jim Stelfox, Alberta Sustainable Resource Development

Marco Fontana, Alberta Conservation Association

Riparian Condition Scoring and Classification:

Interior Reforestation Ltd., Cranbrook, B.C.

Technical Evaluation:

Ed Karpuk, Alberta Sustainable Resource Development

DVD Production:

E Studios Inc., Calgary, $A B$

Reviewers:

Al Sosiak, Brian Hills, Gary Byrtus, Rob Wolfe, Alberta Environment

Front Cover Photo: Cottonwood tree, Oldman River

Ian Dyson, Alberta Environment 
TABLE OF CONTENTS

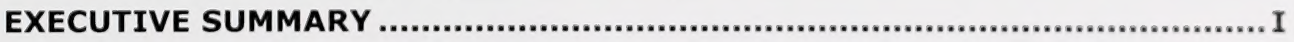

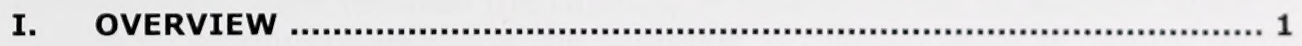

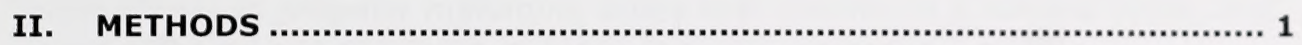

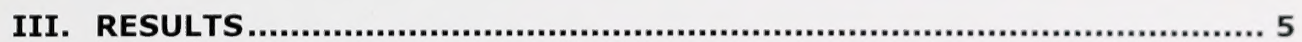

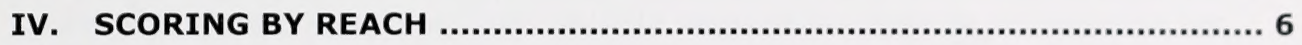

V. SUMMARY OF INDEPENDENT EVALUATION OF METHODOLOGY ......... 26

VI. CONCLUSIONS AND RECOMMENDATIONS................................. 26

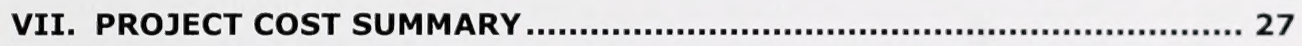

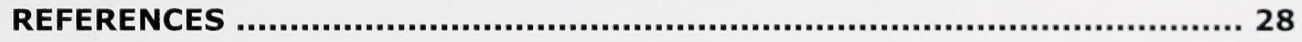

APPENDICES 


\section{Introduction}

Riparian areas perform an important role in ecosystem functioning by trapping sediment, recycling nutrients, recharging groundwater, stabilizing stream banks, regulating water temperature, and creating habitat for aquatic and terrestrial life. Human activities, especially agriculture and urban development, have reduced the capacity of riparian areas to perform these functions. An understanding of the condition of riparian areas is needed to guide efforts in properly managing areas that are still in a natural state, and improving land use practices in areas that are degraded.

Traditional, ground-based methods of assessing riparian condition can be costly and time consuming, and usually require landowner permission for carrying out the work. Airborne methods may be a practical, cost-effective alternative, even though they cannot match the accuracy of ground-based methods. This report summarizes the results of a pilot study using aerial videography, and reports on the efficacy of using the method for assessing riparian condition of selected rivers and streams in southern Alberta. A set of DVDs containing the aerial video of the reaches flown is appended to the report.

\section{Methods}

Helicopter flights were carried out on September $19^{\text {th }}, 2006$ in a portion of the Oldman River Basin west of Highway 2, and on Sept. $23^{\text {rd }}$ in the Bow River Basin near the City of Calgary (Figures 1 and 2). Approximately $750 \mathrm{~km}$ of riparian area along 18 separate reaches were flown at different altitudes and angles relative to the shorelines, adjacent floodplains, and uplands. With the exception of the Bow River, where left and right banks were flown separately, all watercourses were flown in a single pass, filming both banks at the same time. Filming was conducted using a hand-held Sony DRC-TRV 900 digital-video camera with MiniDV-tape format, and attached to a Red Hen Systems VMS-300 GPS processor. The right rear door of the helicopter was removed to facilitate filming.

Most of the filming was conducted in rural areas at an altitude of about 30 to $100 \mathrm{~m}$ above the terrain, and at a speed of about 60-80 kph. Care was taken to avoid disturbing residences and livestock. For logistical reasons, authorization to fly at low altitude over the City of Calgary was not requested, nor was filming within city limits attempted. Nonetheless, contact with air traffic control was maintained at all times while flying near the City of Calgary. Filming over the City of Airdrie and the Town of Cochrane was carried out at an altitude of $330 \mathrm{~m}$ (1000 ft.) above the ground. Permission to film along the Elbow River within the Tsuu T'ina Nation Reserve Lands was requested, but was not obtained. 


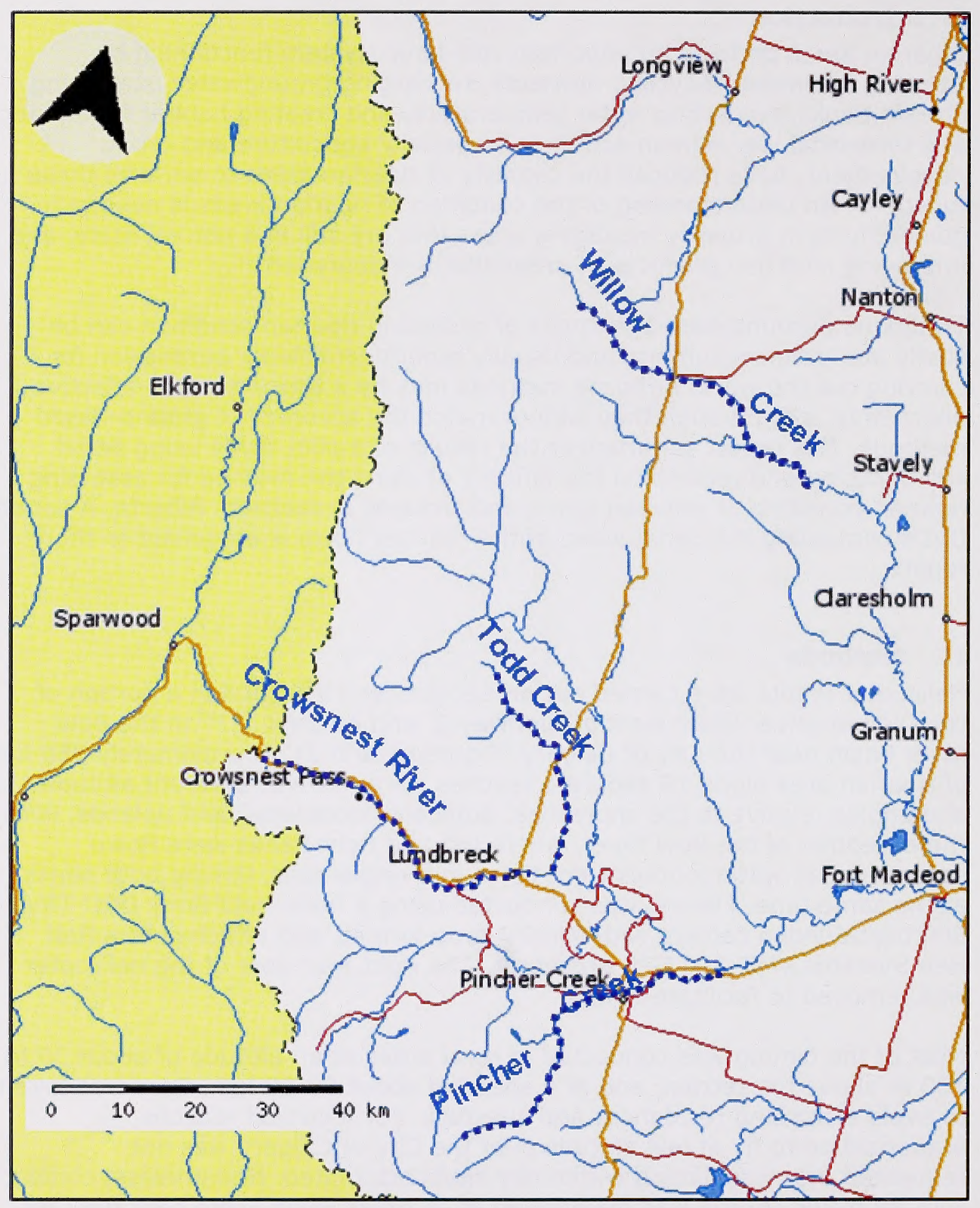

Figure 1. Map with bold, dashed lines showing the locations of streams flown in the Oldman River Basin west of Highway 2. 


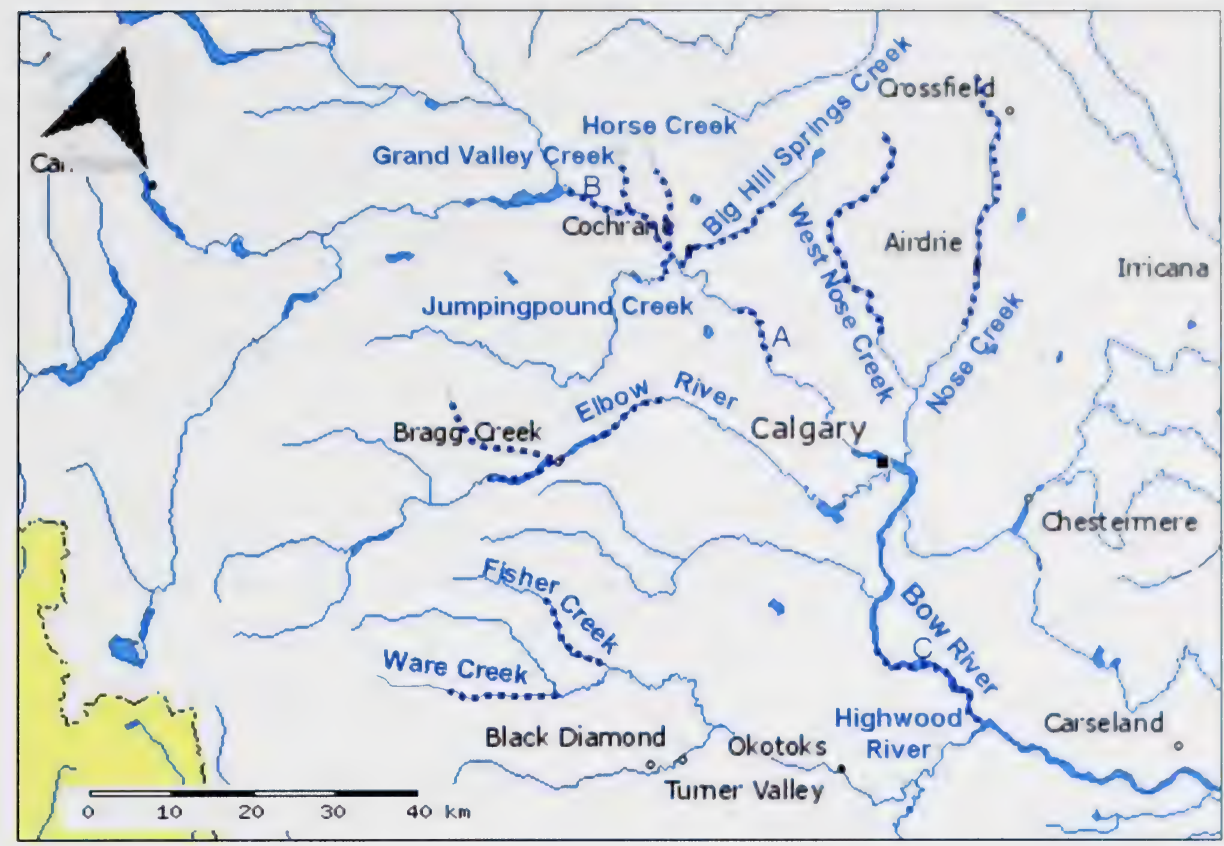

Figure 2. Map with bold, dashed lines showing the locations of streams flown in the Bow River Basin near the City of Calgary. A, B and $\mathrm{C}$ indicate reaches flown along the Bow River. 
Post-flight processing was conducted using Red Hen MediaMapper and ESRI Arcview software. Index and feature layers (point shapefiles ${ }^{1}$ ) were created from the geo-referenced tapes and then mapped in a GIS. An orthographic imagery base was added to show terrain features. Using an automated offset process, lines were generated to approximate the location of the riparian areas on either side of each watercourse flown. In general, the condition of both left and right banks ${ }^{2}$ was assessed and scored to account for differences in land use on opposite sides of the watercourse. Once the condition of the riparian areas was scored, the lines were colour-coded to make the maps easier to read.

A consultant was hired to independently assess and score the condition of the riparian areas using a method adapted from other approaches currently in use (Fitch et al. 2001; Mills and Scrimgeour 2004). Appendix 1 contains a detailed description of the scoring method.

In brief, riparian condition on each side of the watercourse was individually scored using the following parameters:

1. Natural vegetation (includes signs of cattle grazing)

2. Observable recruitment of tree species (tree-shrub cover type only)

3. Plowed or human-caused bare ground

4. Bank armouring or channelization

5. Bank instability (human activity)

6. Flood water access

7. Developed: hard-surface roads, parking areas, structures

Next, the scores were used to classify riparian area sections (breaks) exhibiting similar characteristics:

- $\quad$ Near natural condition (score of 81-100): means that human disturbances and alterations relative to the seven parameters selected for this study appear to be minimal, and vegetation appears to be healthy and in natural condition.

- $\quad$ Moderately impacted (score of 51-80): means that some signs of stress are clearly apparent relative to the seven parameters selected for this study. The reach may be more vulnerable to erosion and be less capable of rebounding from floods and human impact. There is some alteration to natural vegetation.

- Most impacted (score of 0-50): means that human impacts relative to the seven parameters selected for this study are prevalent. The likelihood that the stability of the riparian area has been severely compromised is high. Alteration to natural vegetation is extensive.

Finally, a resource inventory specialist from Alberta Sustainable Resource Development conducted an independent evaluation of the methodology and results, as well as a detailed reach-by-reach evaluation of the scoring for Todd Creek (Appendix 2).

\footnotetext{
A point shapefile is a type of geospatial vector data format for GIS software. Assigned attributes describe the item they represent, in this case the health score of a riparian area.

${ }^{2}$ Left and right banks apply from the perspective of looking downstream, in the direction the current is going.
} 


\section{Results}

A variety of watercourses located in forest, foothills, and grassland natural regions was video-taped and the imagery transferred to DVD (Table 1 ). Time codes and geographical coordinates are provided for geo-referencing purposes. Appendix 3 contains a complete set of the DVDs.

Table 1. Reaches Flown with Time Codes and Location (in order of reaches flown)

\begin{tabular}{|c|c|c|c|c|}
\hline \multirow[b]{3}{*}{ Stream Reach } & \multicolumn{2}{|c|}{ Time Codes } & \multicolumn{2}{|c|}{ Location } \\
\hline & Start & End & Start & End \\
\hline & Hr:Min:Sec & Hr:Min:Sec & $\begin{array}{l}\text { Longitude } \\
\text { Latitude }\end{array}$ & $\begin{array}{l}\text { Longitude } \\
\text { Latitude }\end{array}$ \\
\hline Pincher Creek & $00: 00: 12$ & $00: 56: 27$ & $\begin{array}{l}114.12005 \mathrm{~W} \\
49.29283 \mathrm{~N}\end{array}$ & $\begin{array}{l}113.79605 \mathrm{~W} \\
49.54644 \mathrm{~N}\end{array}$ \\
\hline Crowsnest River & $00: 02: 34$ & $00: 56: 44$ & $\begin{array}{l}114.09577 \mathrm{~W} \\
49.59235 \mathrm{~N}\end{array}$ & $\begin{array}{l}114.61703 \mathrm{~W} \\
49.63067 \mathrm{~N}\end{array}$ \\
\hline Todd Creek & $00: 04: 24$ & $00: 46: 59$ & $\begin{array}{l}114.12285 \mathrm{~W} \\
49.60431 \mathrm{~N}\end{array}$ & $\begin{array}{l}114.32134 \mathrm{~W} \\
49.79979 \mathrm{~N}\end{array}$ \\
\hline Willow Creek & 00:00:00 & $1: 02: 15$ & $\begin{array}{l}114.41408 \mathrm{~W} \\
50.27965 \mathrm{~N}\end{array}$ & $\begin{array}{c}113.88813 \mathrm{~W} \\
50.12733 \mathrm{~N}\end{array}$ \\
\hline Nose Creek & $00: 00: 00$ & $00: 23: 53$ & $\begin{array}{l}114.04917 \mathrm{~W} \\
51.41138 \mathrm{~N}\end{array}$ & $\begin{array}{c}114.00943 \mathrm{~W} \\
51.18701 \mathrm{~N}\end{array}$ \\
\hline West Nose Creek & $00: 00: 26$ & $00: 24: 45$ & $\begin{array}{l}114.13359 \mathrm{~W} \\
51.18530 \mathrm{~N}\end{array}$ & $\begin{array}{c}114.23030 \mathrm{~W} \\
51.38743 \mathrm{~N}\end{array}$ \\
\hline Grand Valley Creek & 00:00:10 & $00: 06: 48$ & $\begin{array}{l}114.60609 \mathrm{~W} \\
51.28949 \mathrm{~N}\end{array}$ & $\begin{array}{l}114.56150 \mathrm{~W} \\
51.22048 \mathrm{~N}\end{array}$ \\
\hline Bow River sec B & $00: 06: 55$ & $00: 17: 26$ & $\begin{array}{l}114.52438 \mathrm{~W} \\
51.19534 \mathrm{~N}\end{array}$ & $\begin{array}{c}114.70549 \mathrm{~W} \\
51.21857 \mathrm{~N}\end{array}$ \\
\hline Horse Creek & $00: 19: 34$ & $00: 26: 58$ & $\begin{array}{c}114.53709 \mathrm{~W} \\
51.28913 \mathrm{~N}\end{array}$ & $\begin{array}{c}114.52292 \mathrm{~W} \\
51.19853 \mathrm{~N}\end{array}$ \\
\hline Big Hill Springs Creek & $00: 27: 12$ & 00:37:09 & $\begin{array}{c}114.36922 \mathrm{~W} \\
51.27459 \mathrm{~N}\end{array}$ & $\begin{array}{c}114.47889 \mathrm{~W} \\
51.18009 \mathrm{~N}\end{array}$ \\
\hline Jumping Pound Creek & $\begin{array}{c}\text { 00:00:26 } \\
\text { (after BHS } \\
\text { Creek) }\end{array}$ & $00: 06: 47$ & $\begin{array}{l}114.53287 \mathrm{~W} \\
51.15260 \mathrm{~N}\end{array}$ & $\begin{array}{l}114.50015 \mathrm{~W} \\
51.18193 \mathrm{~N}\end{array}$ \\
\hline Bow River sec $A$ & 00:00:00 & 00:04:09 & $\begin{array}{c}114.36120 \mathrm{~W} \\
51.15935 \mathrm{~N}\end{array}$ & $\begin{array}{c}114.30846 \mathrm{~W} \\
51.12993 \mathrm{~N} \\
\end{array}$ \\
\hline Elbow River & $00: 06: 50$ & $00: 34: 37$ & $\begin{array}{c}114.25308 \mathrm{~W} \\
51.02132 \mathrm{~N}\end{array}$ & $\begin{array}{c}114.48921 \mathrm{~W} \\
51.00963 \mathrm{~N}\end{array}$ \\
\hline Bragg Creek & $00: 34: 45$ & $00: 46: 26$ & $\begin{array}{c}114.76217 \mathrm{~W} \\
50.97759 \mathrm{~N}\end{array}$ & $\begin{array}{c}114.57589 \mathrm{~W} \\
50.94815 \mathrm{~N}\end{array}$ \\
\hline Fisher Creek & 00:00:29 & $00: 08: 43$ & $\begin{array}{l}114.52250 \mathrm{~W} \\
50.80500 \mathrm{~N}\end{array}$ & $\begin{array}{c}114.38863 \mathrm{~W} \\
50.76027 \mathrm{~N}\end{array}$ \\
\hline Ware Creek & 00:09:05 & $00: 14: 25$ & $\begin{array}{c}114.45417 \mathrm{~W} \\
50.71505 \mathrm{~N}\end{array}$ & $\begin{array}{c}114.52476 \mathrm{~W} \\
50.71217 \mathrm{~N}\end{array}$ \\
\hline $\begin{array}{c}\text { Bow River sec C Right } \\
\text { Bank }\end{array}$ & $00: 15: 32$ & $00: 08: 58$ & $\begin{array}{l}113.98770 \mathrm{~W} \\
50.86439 \mathrm{~N}\end{array}$ & $\begin{array}{c}113.78146 \mathrm{~W} \\
50.81994 \mathrm{~N}\end{array}$ \\
\hline $\begin{array}{c}\text { Bow River sec C Left } \\
\text { Bank }\end{array}$ & $00: 29: 15$ & $00: 44: 04$ & $\begin{array}{c}113.77907 \mathrm{~W} \\
50.81795 \mathrm{~N}\end{array}$ & $\begin{array}{c}113.99604 \mathrm{~W} \\
50.88433 \mathrm{~N}\end{array}$ \\
\hline
\end{tabular}


Viewing angles included both banks (Figure 3), except for the Bow River where left and right banks were video-taped separately (Figure 4).

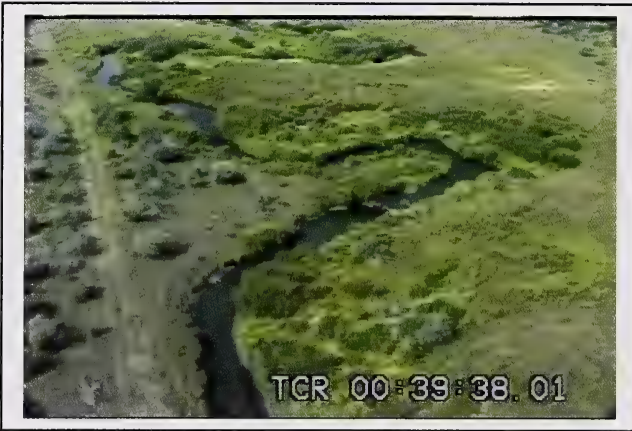

Figure 3. Todd Creek

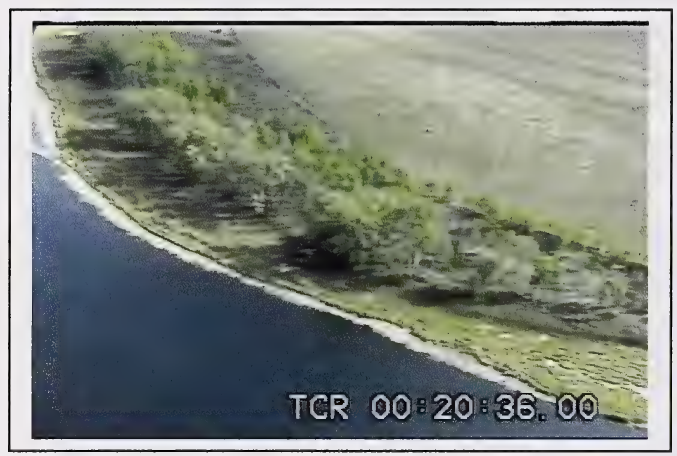

Overall, the quality of the videos was adequate for identification of ground details such as cattle grazing and vehicular activity (Figures 4 \& 5).

Figure 4. Bow River

Several factors affected video quality, including light conditions and the altitude, speed, and position of the helicopter. In some areas, dense tree cover made it hard to see the condition of the ground, while in others stream sinuosity made maintaining close contact with the stream difficult.

\section{Scoring by Reach}

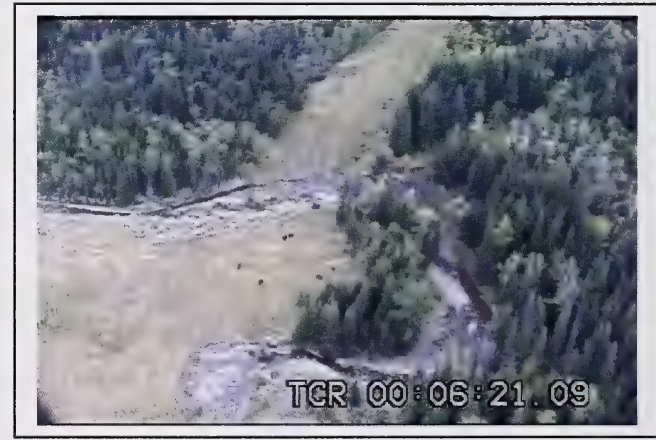

Figure 5. Pincher Creek

Pie charts in this section summarize the riparian area scores, along with a colour-coded map, for each reach. The coloured lines show the approximate location of the riparian areas on either side of the watercourse. Time stamps show when the score changes within a reach, and can be used as reference when viewing the DVDs. The Crowsnest River had frequent changes in riparian score along its course, and consequently charts containing the times are included instead of time stamps for easier reference. Individual pie charts are shown for left and right banks except for watercourses that had identical scores on opposite banks; combined pie charts are shown for these watercourses. 


\section{Pincher Creek}

Reach flown: From near its source in the western part of Twp 4, Rge 1, W5M in the Rocky Mountains Forest Reserve to its confluence with the Oldman River.
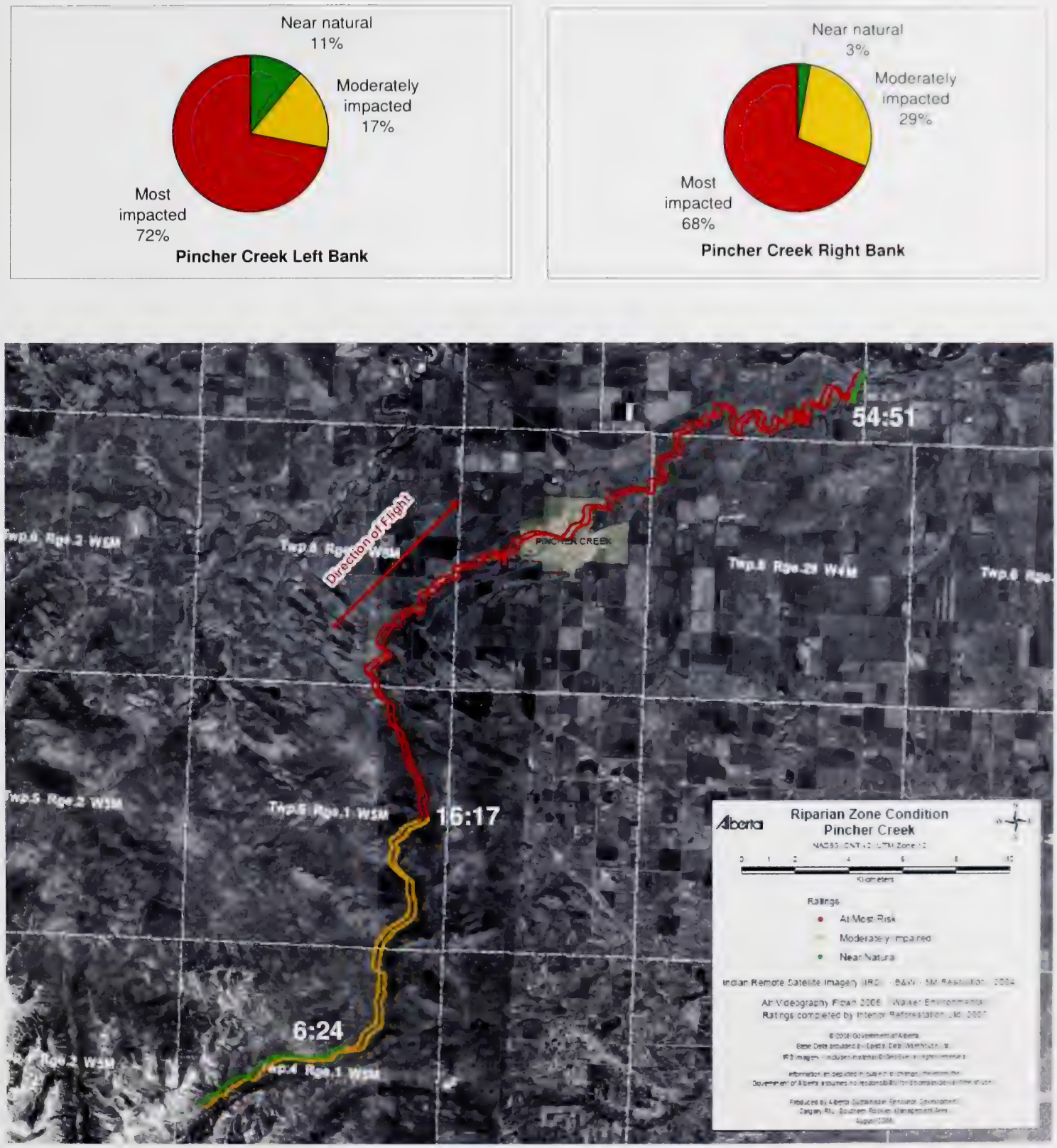


\section{Crowsnest River}

Reach flown: From the Oldman River Reservoir to Crowsnest Lake.
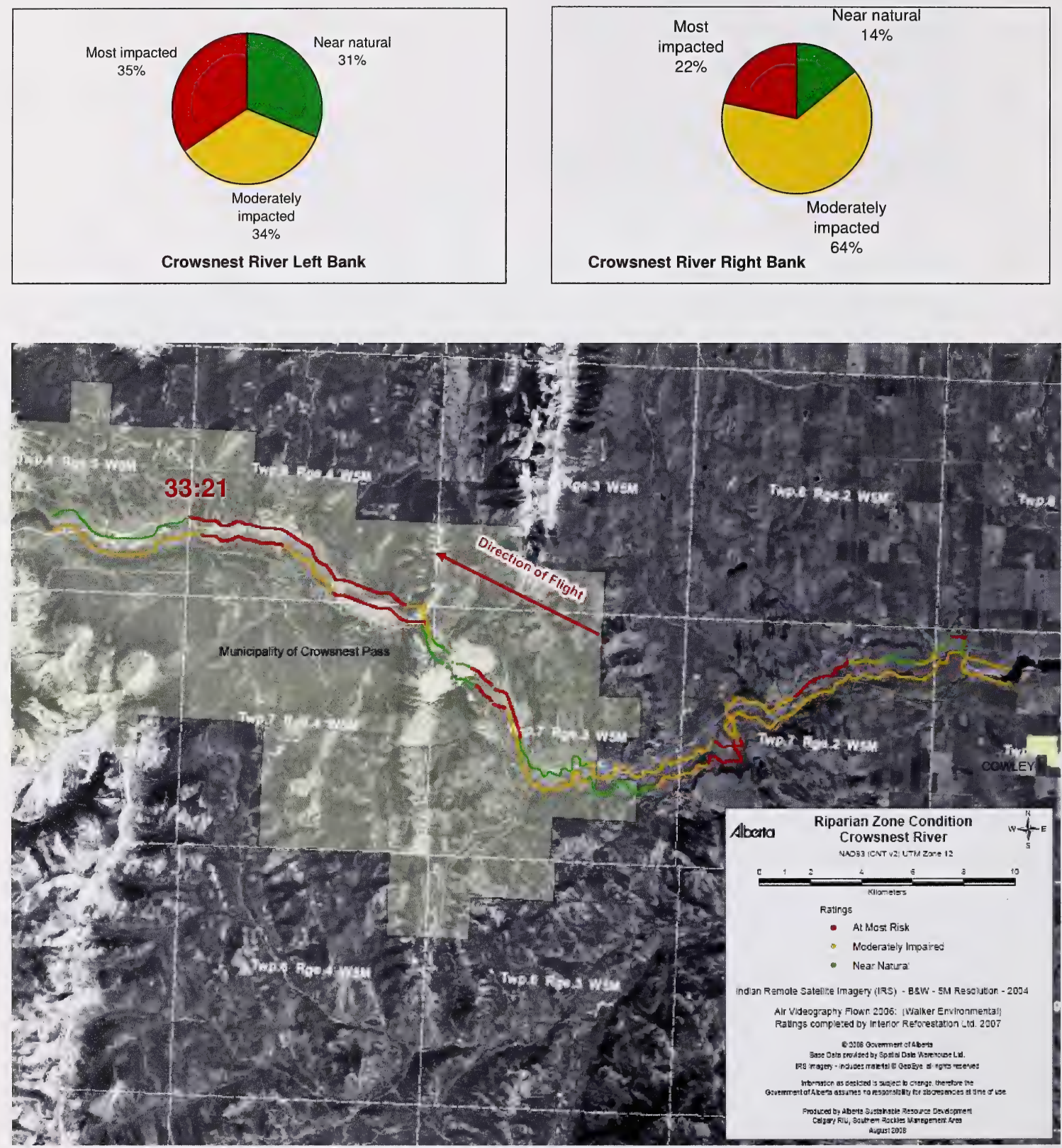

Note: The Crowsnest River had frequent changes in riparian score along its course, and consequently charts containing the times are included instead of time stamps for easier reference (see next page). 
Left Bank

\begin{tabular}{|c|c|c|}
\hline \multicolumn{2}{|c|}{ Crowsnest River } & Tree/shrub \\
\hline 志 & 它 & Classification Condition \\
\hline $0: 02: 34$ & $0: 03: 50$ & Moderately Impacted \\
\hline $0: 03: 51$ & $0: 04: 24$ & Near Natural \\
\hline $0: 04: 25$ & 0:05:04 & Most Impacted \\
\hline $0: 05: 05$ & $0: 05: 54$ & Near Natural \\
\hline $0: 05: 55$ & $0: 07: 16$ & Moderately Impacted \\
\hline $0: 07: 17$ & $0: 08: 43$ & Near Natural \\
\hline $0: 08: 44$ & $0: 10: 29$ & Moderately Impacted \\
\hline $0: 10: 30$ & $0: 13: 26$ & Most Impacted \\
\hline $0: 13: 27$ & $0: 18: 05$ & Moderately Impacted \\
\hline $0: 18: 06$ & $0: 19: 44$ & Most Impacted \\
\hline $0: 19: 45$ & $0: 25: 18$ & Moderately Impacted \\
\hline $0: 25: 19$ & $0: 26: 59$ & Moderately Impacted \\
\hline $0: 27: 00$ & $0: 32: 28$ & Near Natural \\
\hline $0: 32: 29$ & $0: 36: 13$ & Most Impacted \\
\hline $0: 36: 14$ & $0: 38: 07$ & Near Natural \\
\hline $0: 38: 08$ & $0: 40: 26$ & Moderately Impacted \\
\hline $0: 40: 27$ & $0: 50: 05$ & Most Impacted \\
\hline $0: 50: 06$ & $0: 56: 42$ & Near Natural \\
\hline
\end{tabular}

\section{Right Bank}

\begin{tabular}{|c|c|c|}
\hline \multicolumn{2}{|c|}{ Crowsnest River } & Tree/shrub \\
\hline 焉 & 岀 & Classification Condition \\
\hline $0: 02: 34$ & $0: 08: 42$ & Moderately I mpacted \\
\hline $0: 08: 43$ & $0: 11: 35$ & Moderately I mpacted \\
\hline $0: 11: 36$ & $0: 13: 13$ & Moderately Impacted \\
\hline $0: 13: 14$ & $0: 16: 10$ & Moderately I mpacted \\
\hline $0: 16: 11$ & $0: 17: 28$ & Moderately I mpacted \\
\hline $0: 17: 29$ & $0: 20: 13$ & Most Impacted \\
\hline $0: 20: 14$ & $0: 22: 58$ & Moderately Impacted \\
\hline $0: 22: 59$ & $0: 27: 10$ & Near Natural \\
\hline $0: 27: 11$ & $0: 34: 21$ & Moderately Impacted \\
\hline $0: 34: 22$ & $0: 36: 04$ & Most Impacted \\
\hline $0: 36: 05$ & $0: 39: 31$ & Near Natural \\
\hline $0: 39: 32$ & $0: 43: 22$ & Most Impacted \\
\hline $0: 43: 23$ & $0: 46: 15$ & Moderately Impacted \\
\hline $0: 46: 16$ & $0: 49: 38$ & Most Impacted \\
\hline $0: 49: 39$ & $0: 56: 42$ & Moderately Impacted \\
\hline
\end{tabular}




\section{Todd Creek}

Reach Flown: From its confluence with the Oldman River to the southeastern part of Twp 10, Rge 3, W5M in the Rocky Mountains Forest Reserve.
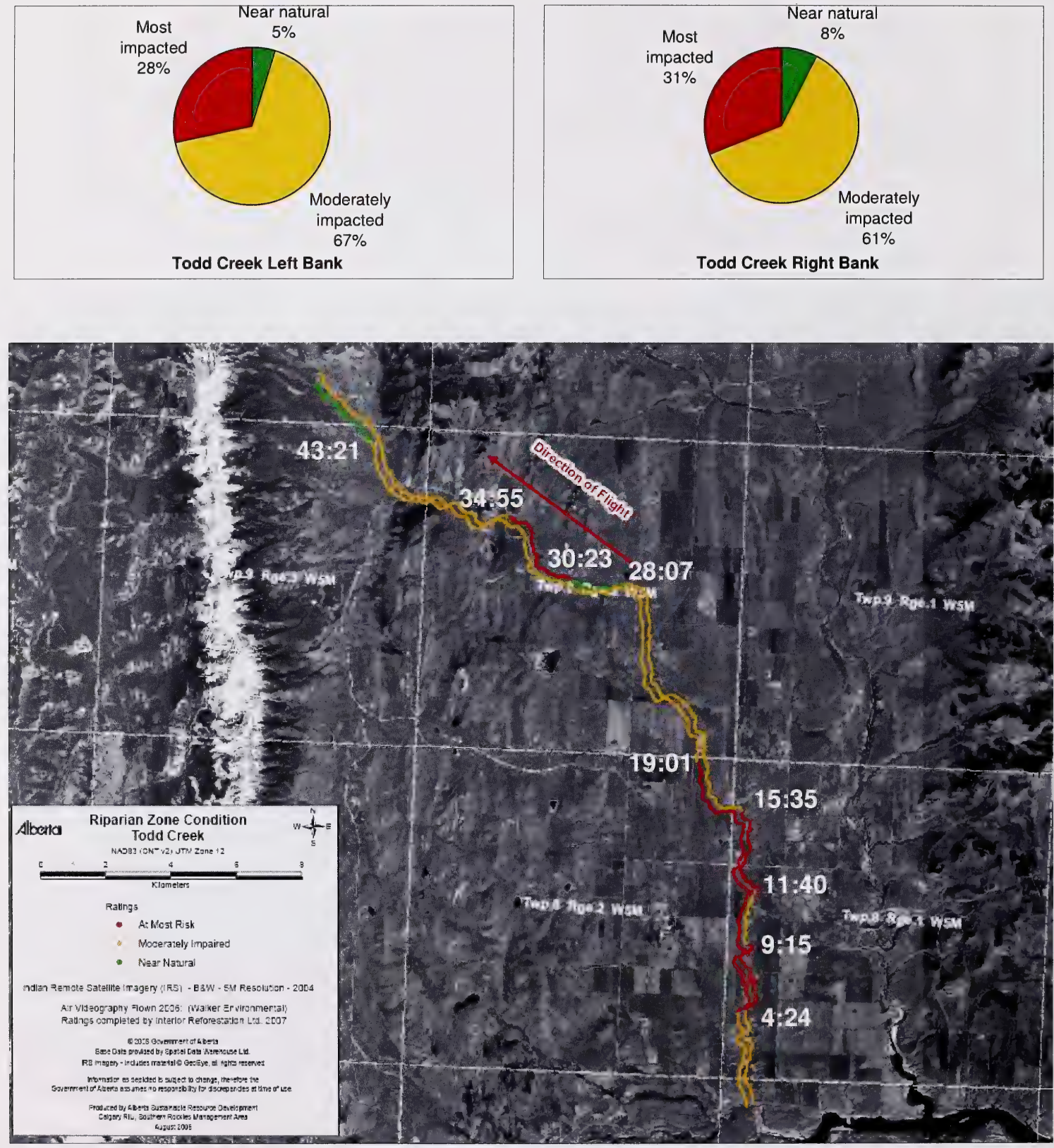


\section{Willow Creek}

Reach Flown: From near its source at the western limit of Twp 15, Rge 3, W5M in the Rocky Mountains Forest Reserve to near the northern limit of Twp 13, Rge 29, W4M.

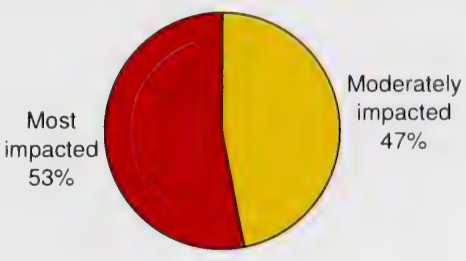

Willow Creek Left Bank

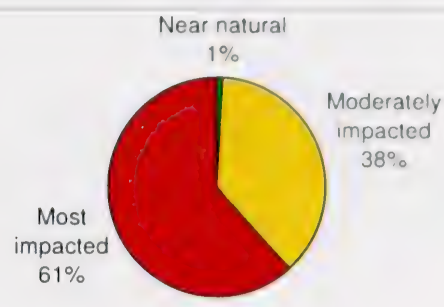

Willow Creek Right Bank

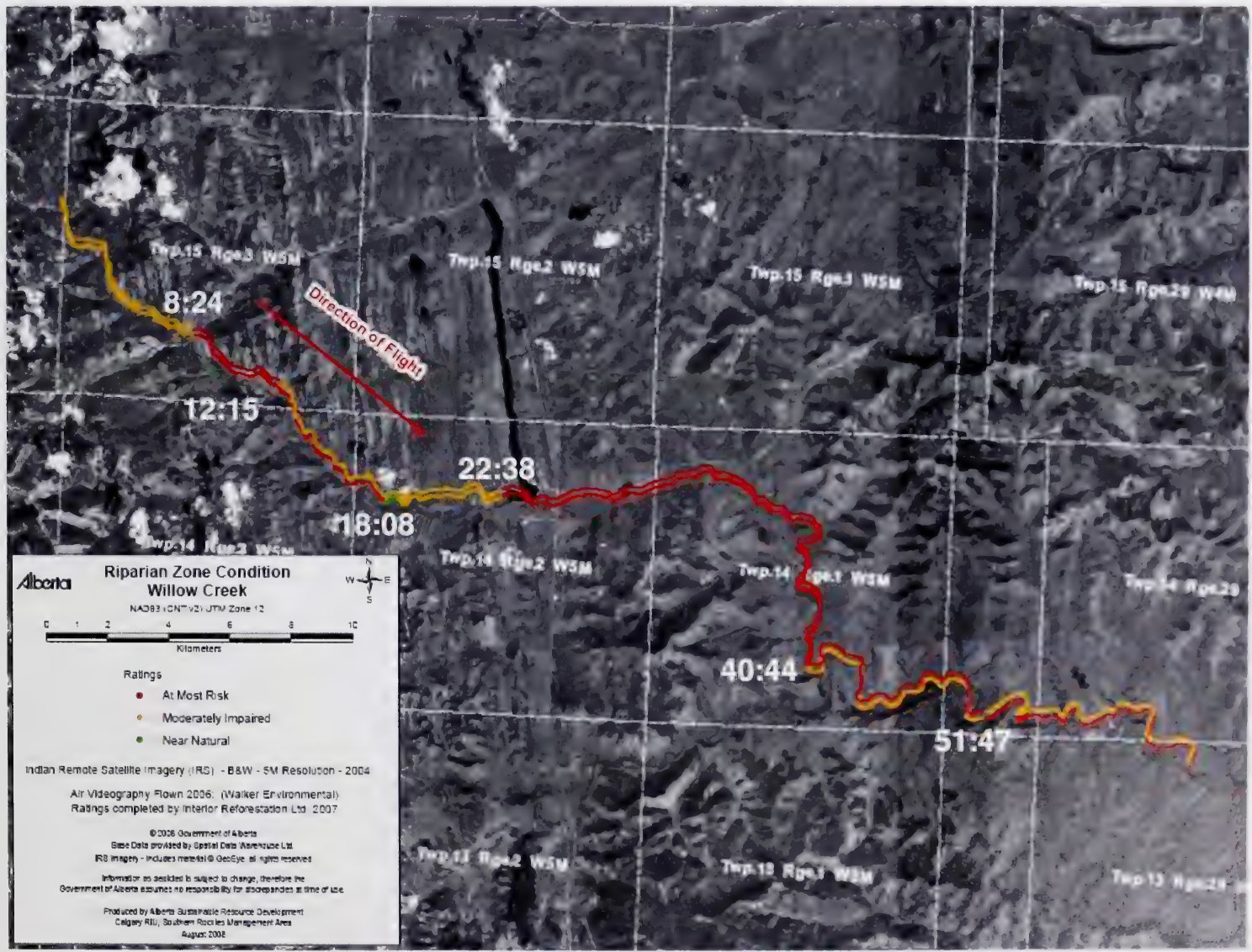




\section{Nose Creek}

Reach Flown: From its source west of the Town of Crossfield to near its crossing with the Calgary city limit.
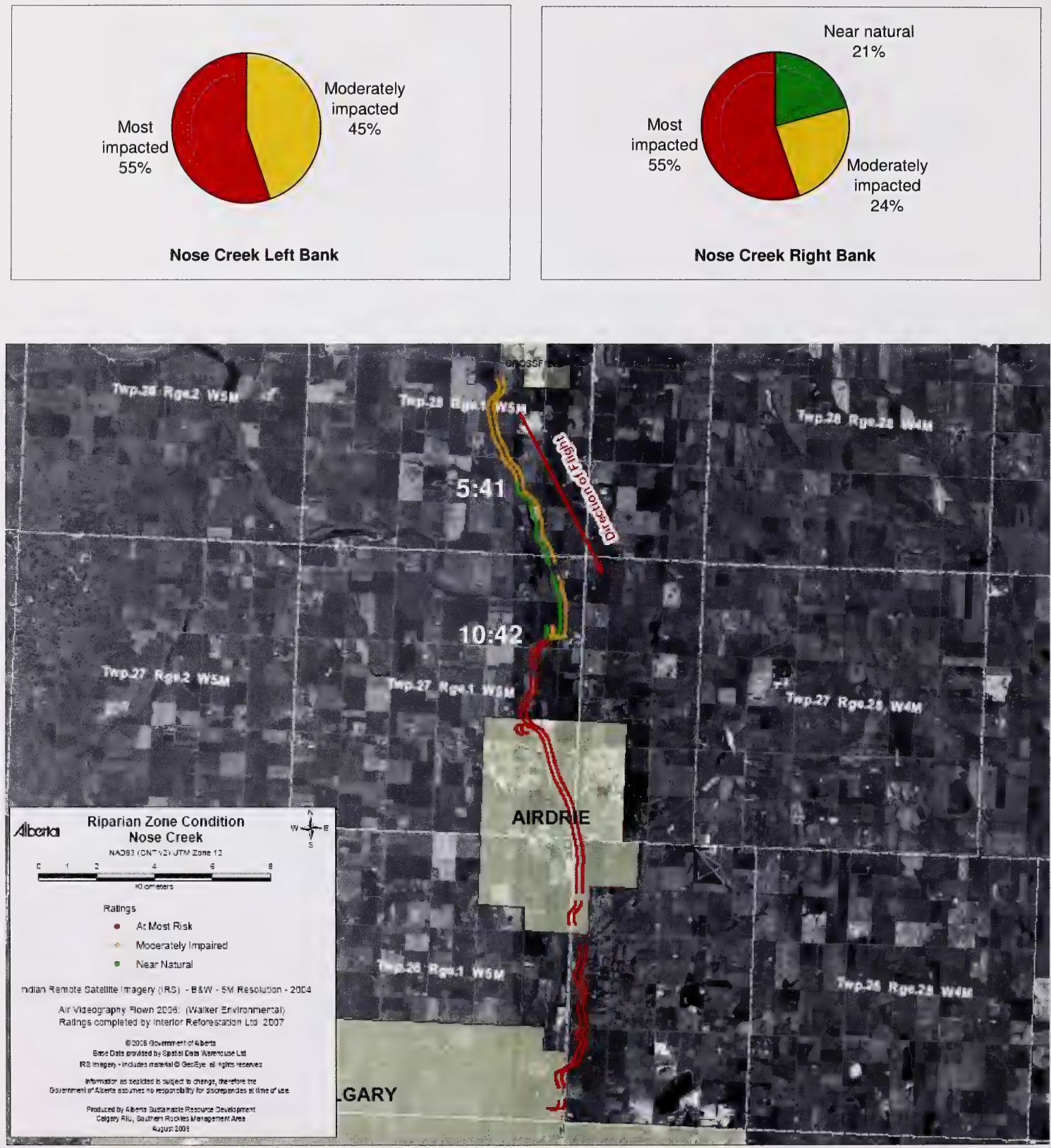


\section{West Nose Creek}

Reach Flown: From near its crossing with the Calgary city limit to near its source in Twp 28, Rge 2, W5M.

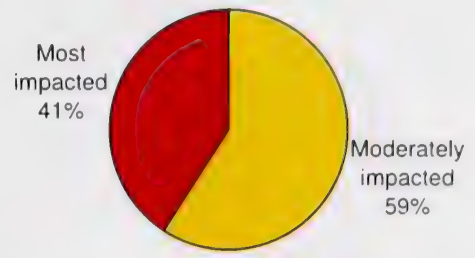

West Nose Creek Both Banks

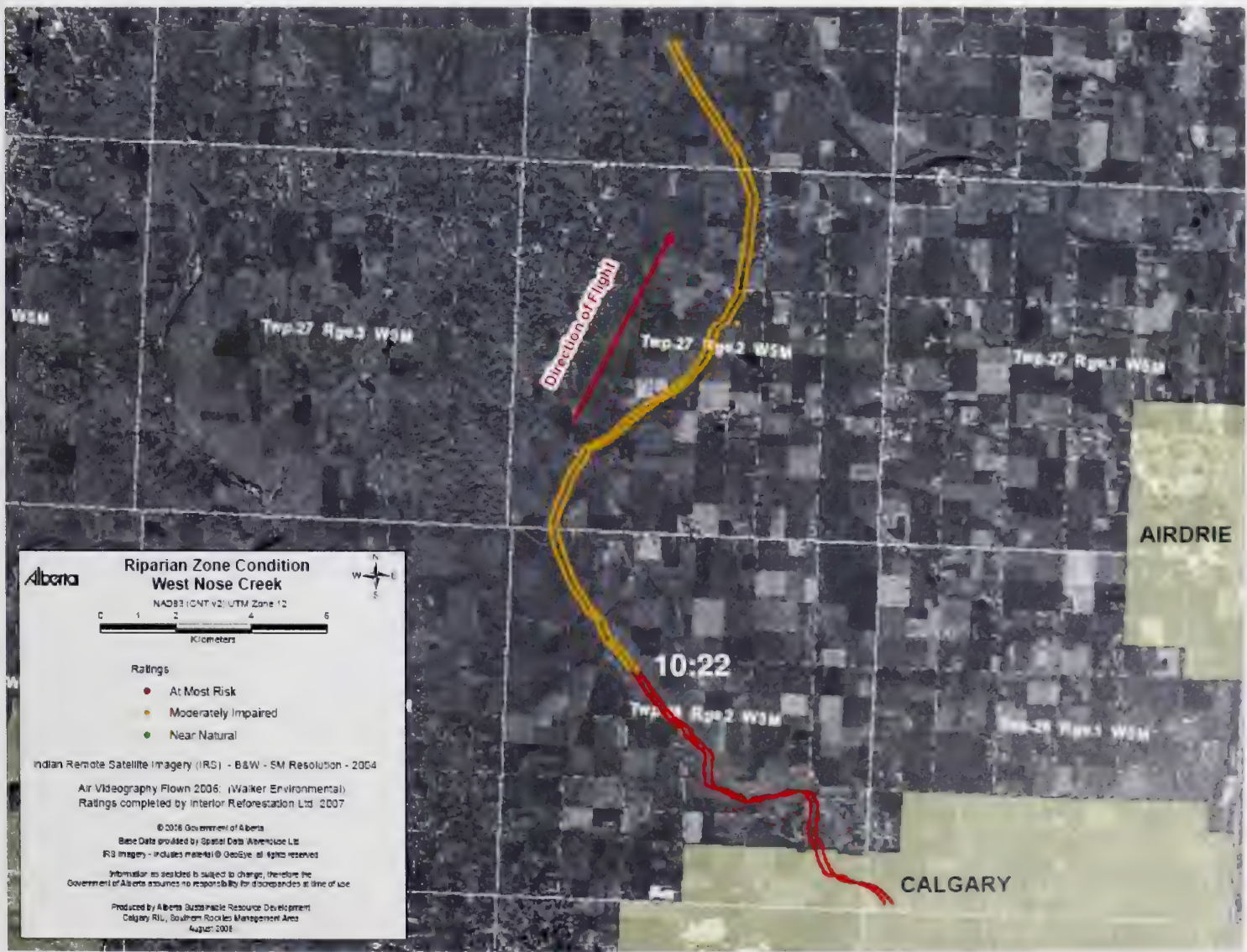




\section{Grand Valley Creek}

Reach Flown: From near its headwaters in Twp 27, Rge 5, W5M to its confluence with the Bow River.
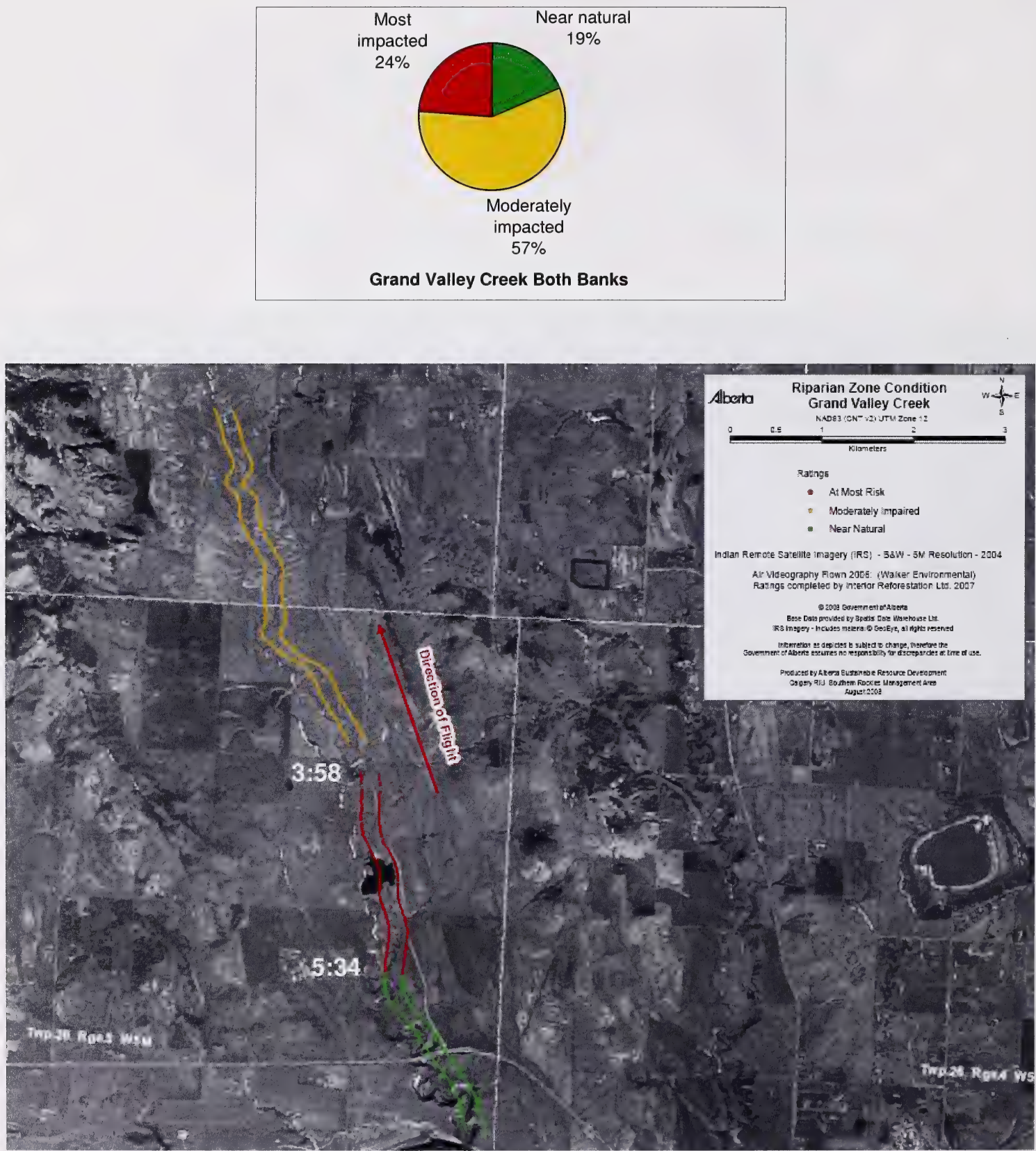


\section{Bow River - Section B, Left Bank}

Reach Flown: From the western limit of the Town of Cochrane to the Ghost Reservoir Dam.

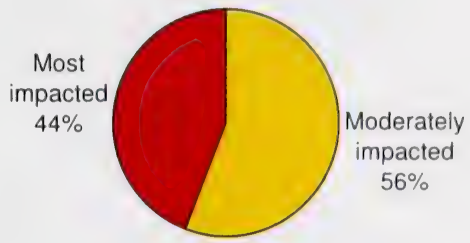

Bow River Section B Left Bank

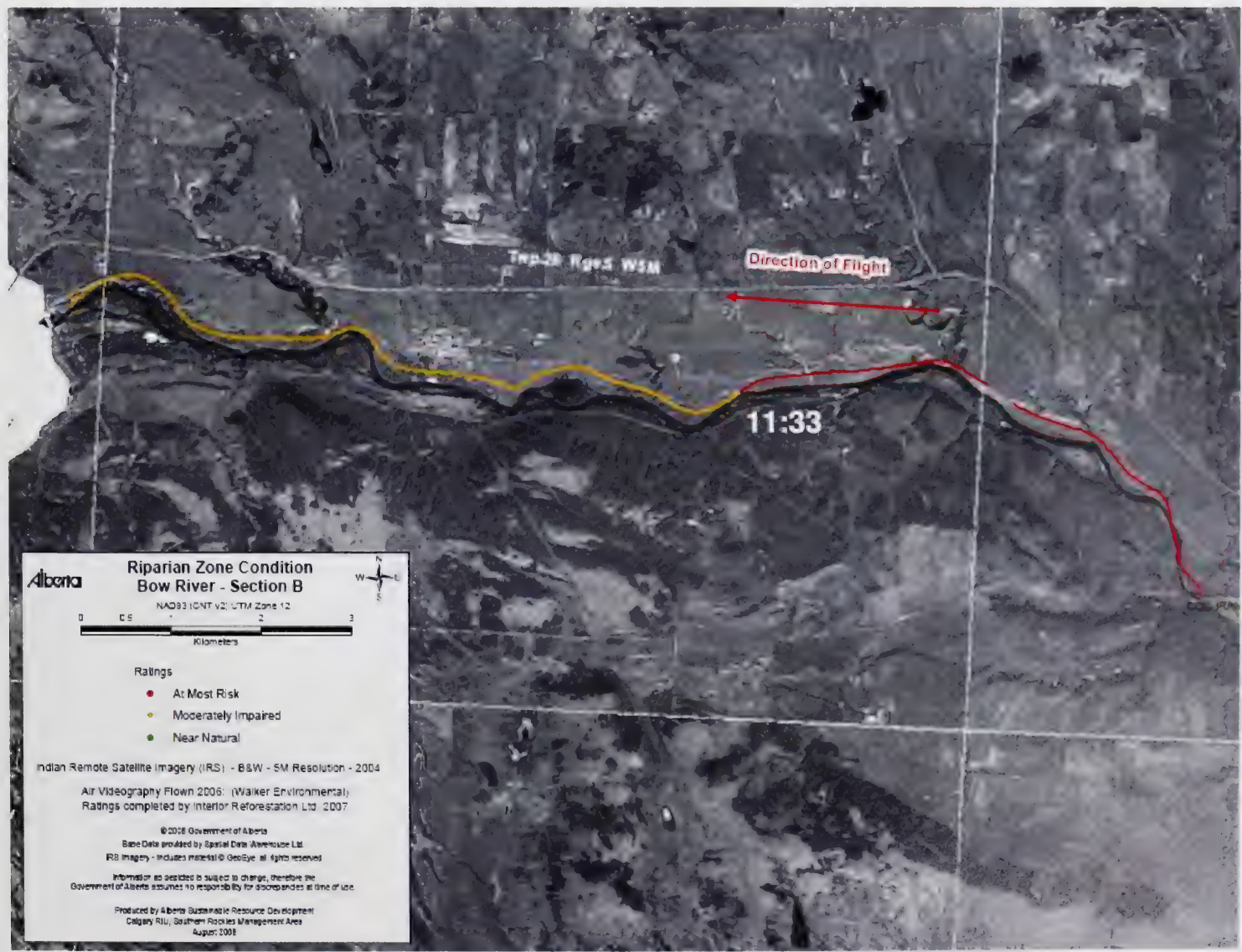




\section{Horse Creek}

Reach Flown: From near its headwaters in Twp 27, Rge 4, W5M to its confluence with the Bow River.
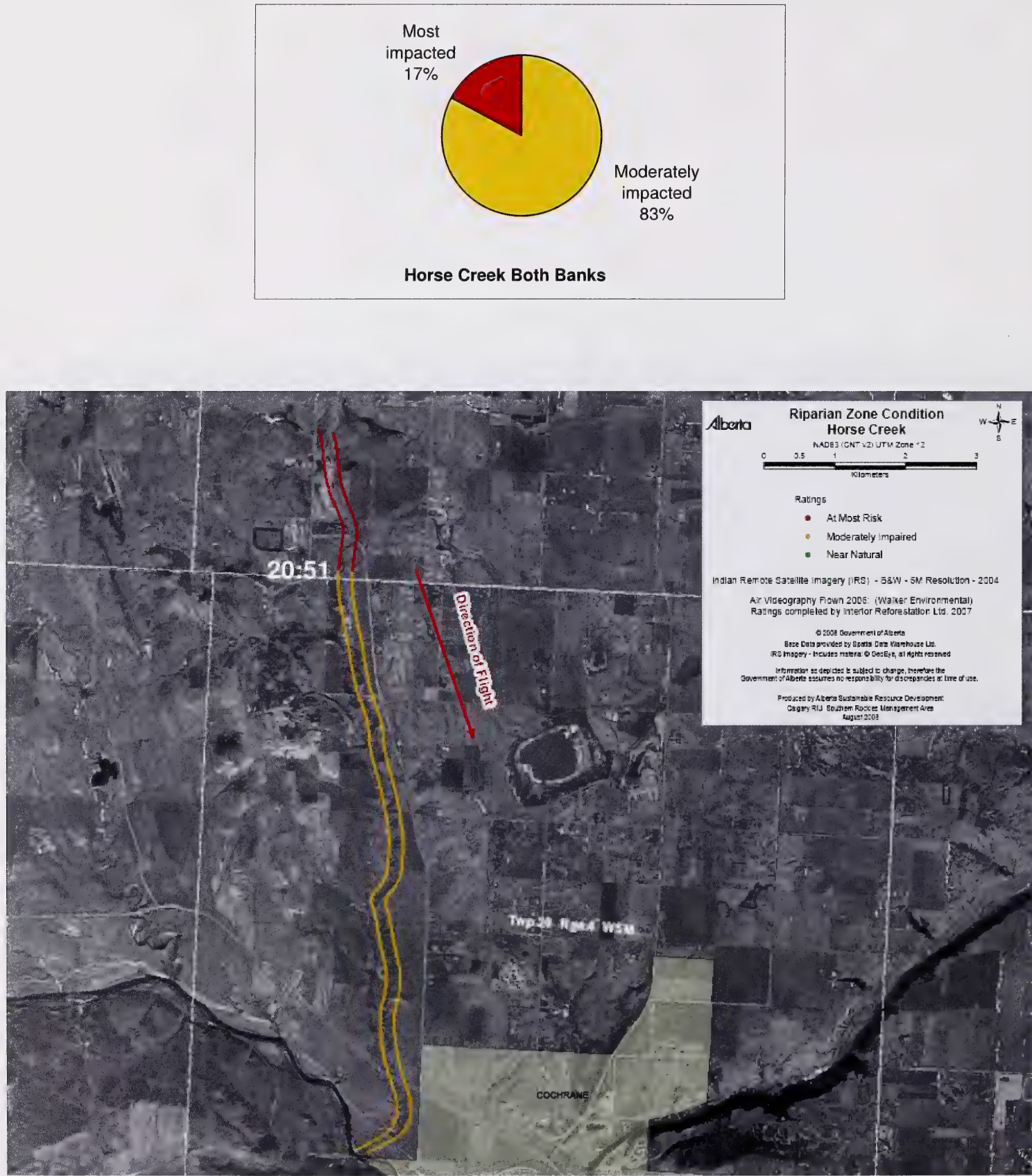


\section{Big Hill Springs Creek}

Reach Flown: From its crossing at Secondary Road 567 (Big Hill Springs Road) through the Town of Cochrane to its confluence with the Bow River.

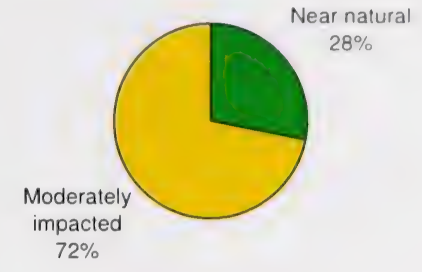

Big Hill Springs Creek Both Banks

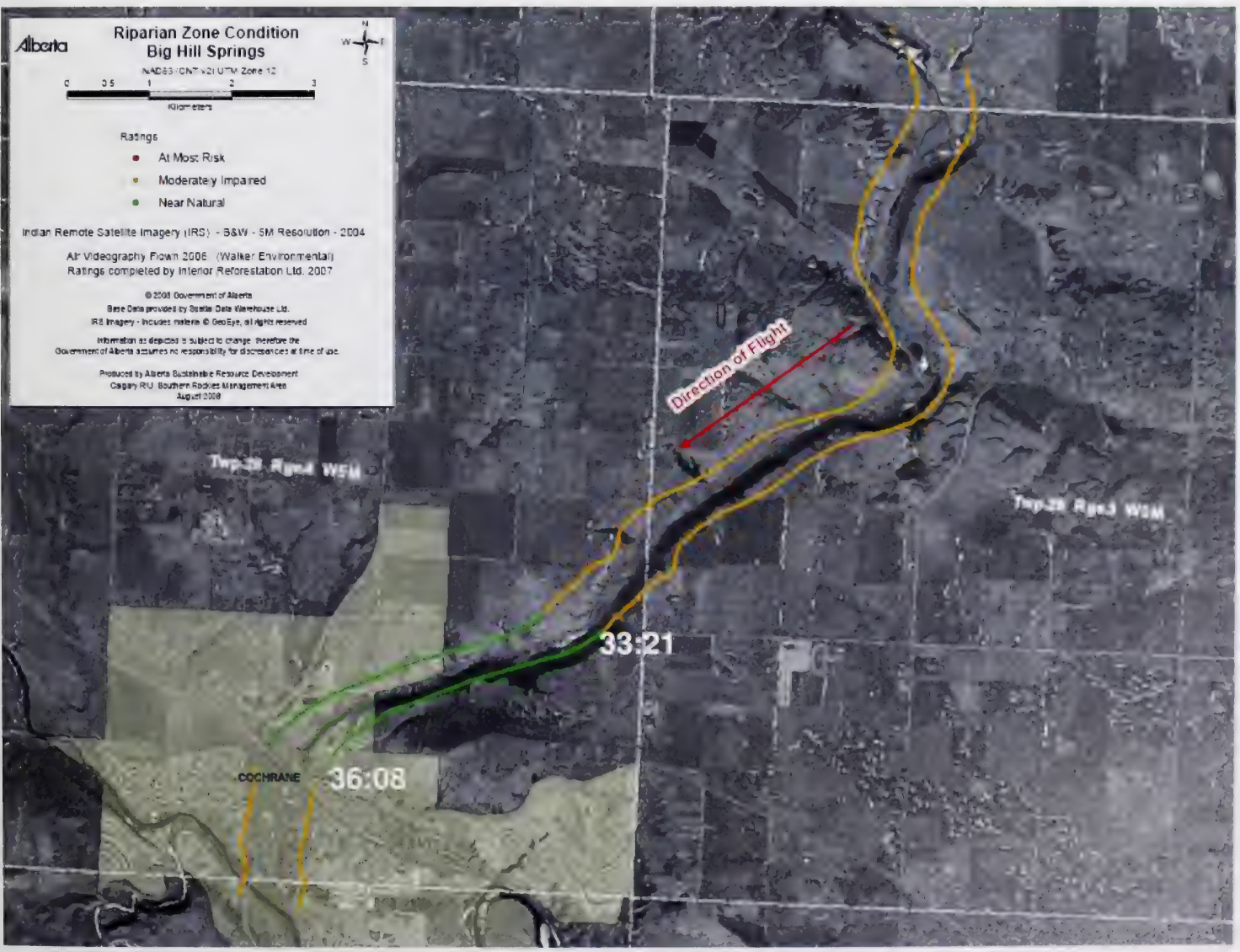




\section{Jumpingpound Creek}

Reach Flown: Approximately a $5 \mathrm{~km}$-reach from a point in Twp 25, Rge 4, W5M to its confluence with the Bow River.
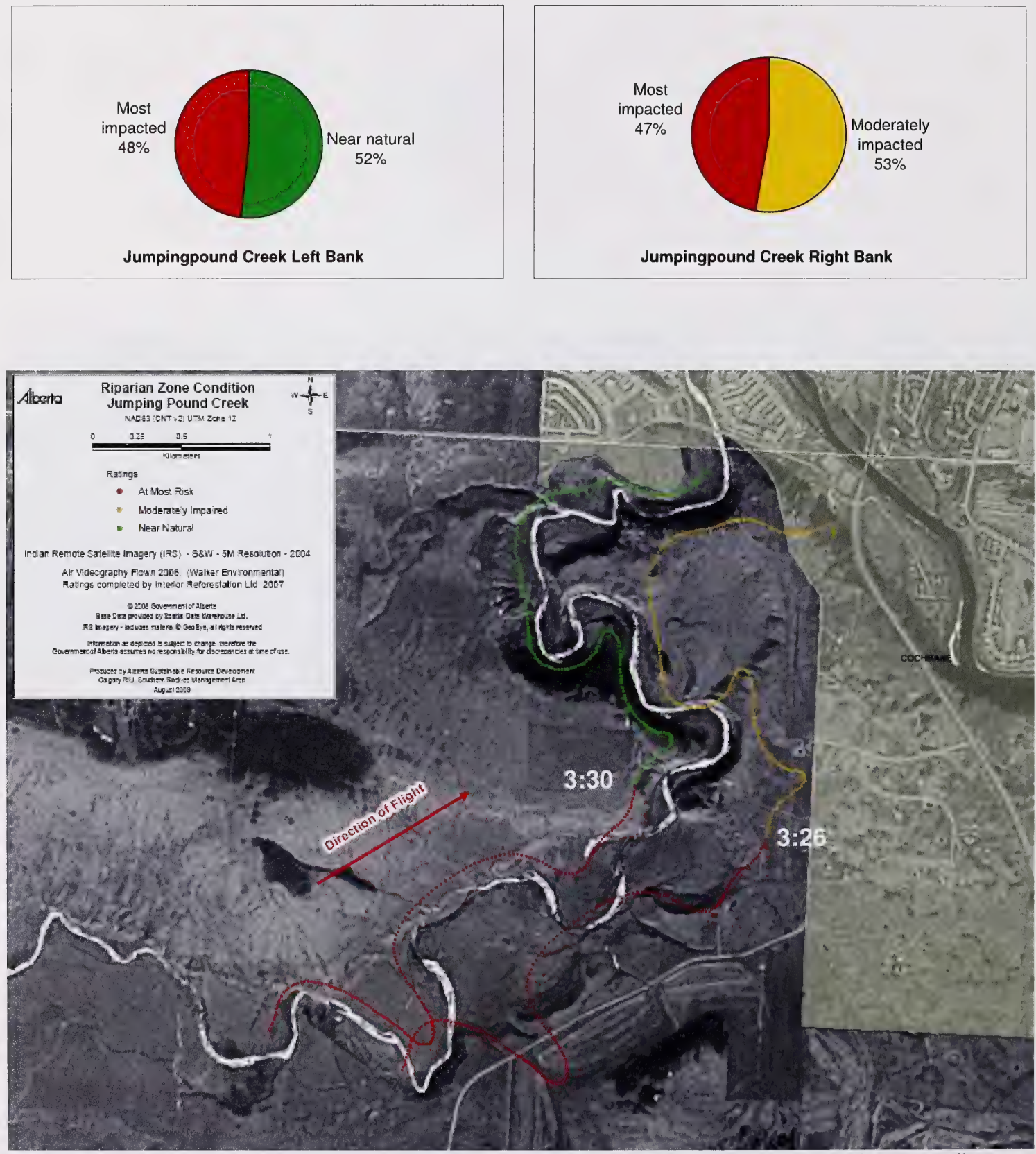

Note: The unusual location of the riparian area line on the right bank of the creek is due to scaling errors induced during the offset-process. 


\section{Bow River - Section A, Right Bank}

Reach Flown: A 5-km reach just upstream from the City of Calgary.

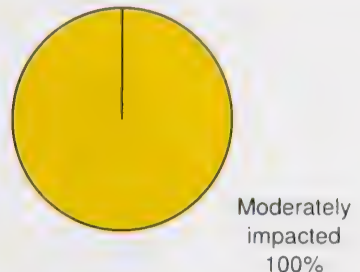

Bow River Section A Right Bank

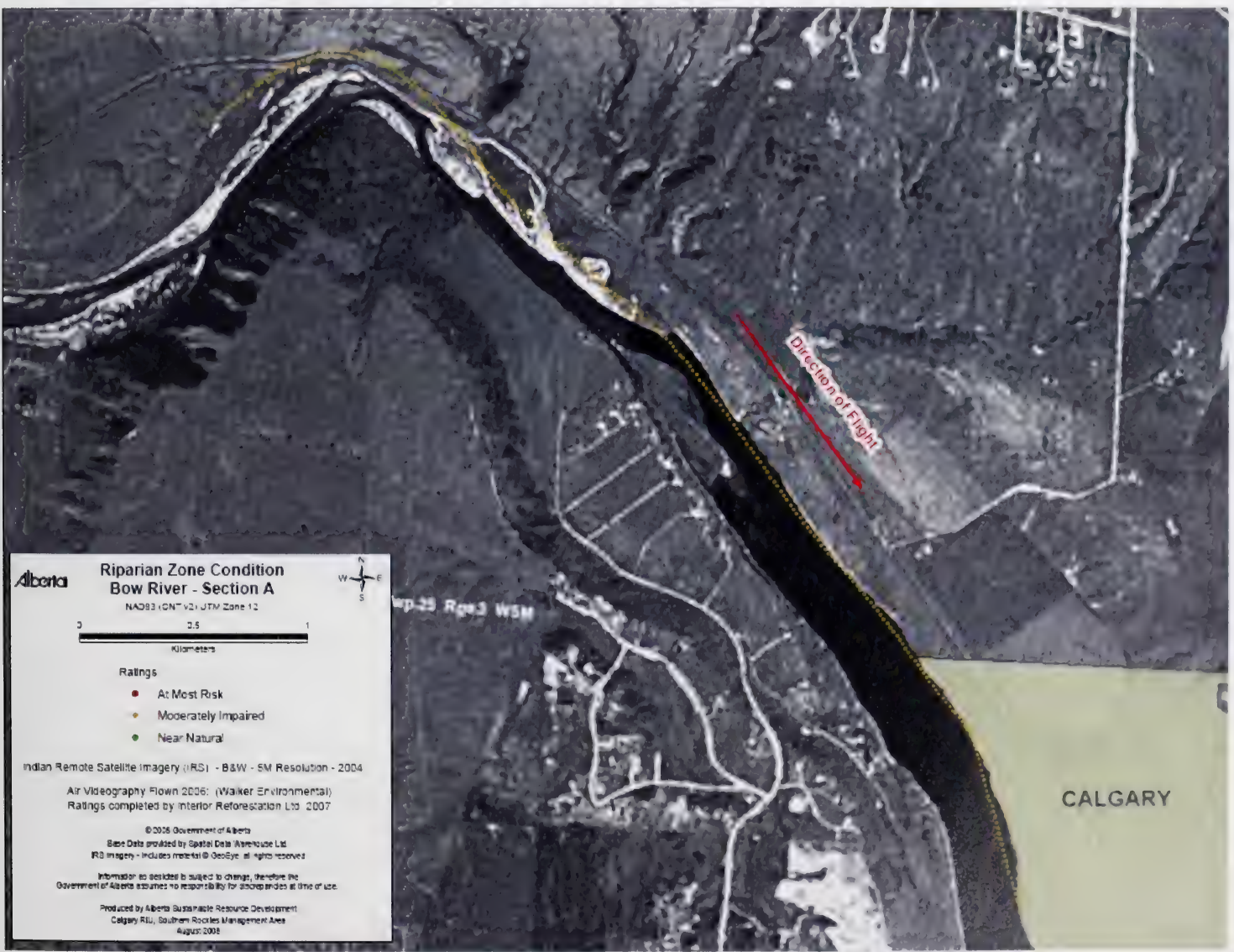




\section{Elbow River}

Reach Flown: From near its crossing at the Calgary city limit to its confluence with Gorge Creek.
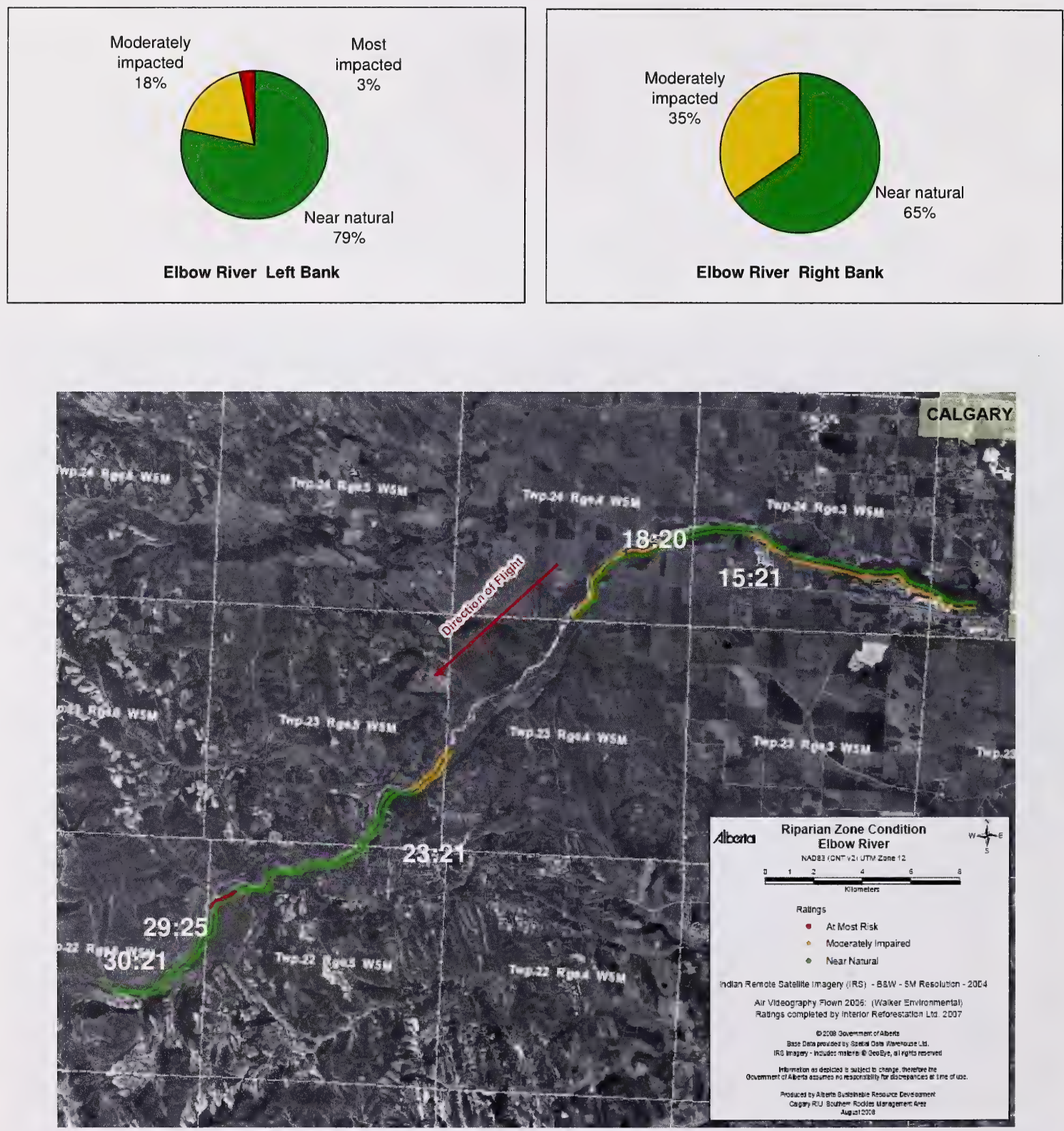

Note: The gap in the scoring corresponds to the Tsuu T'ina Nations Reserve Lands where the video camera was turned off. 


\section{Bragg Creek}

Reach Flown: From its headwaters in Twp 23, Rge 6, W5M, northwest of the Hamlet of Bragg Creek, to its confluence with the Elbow River.
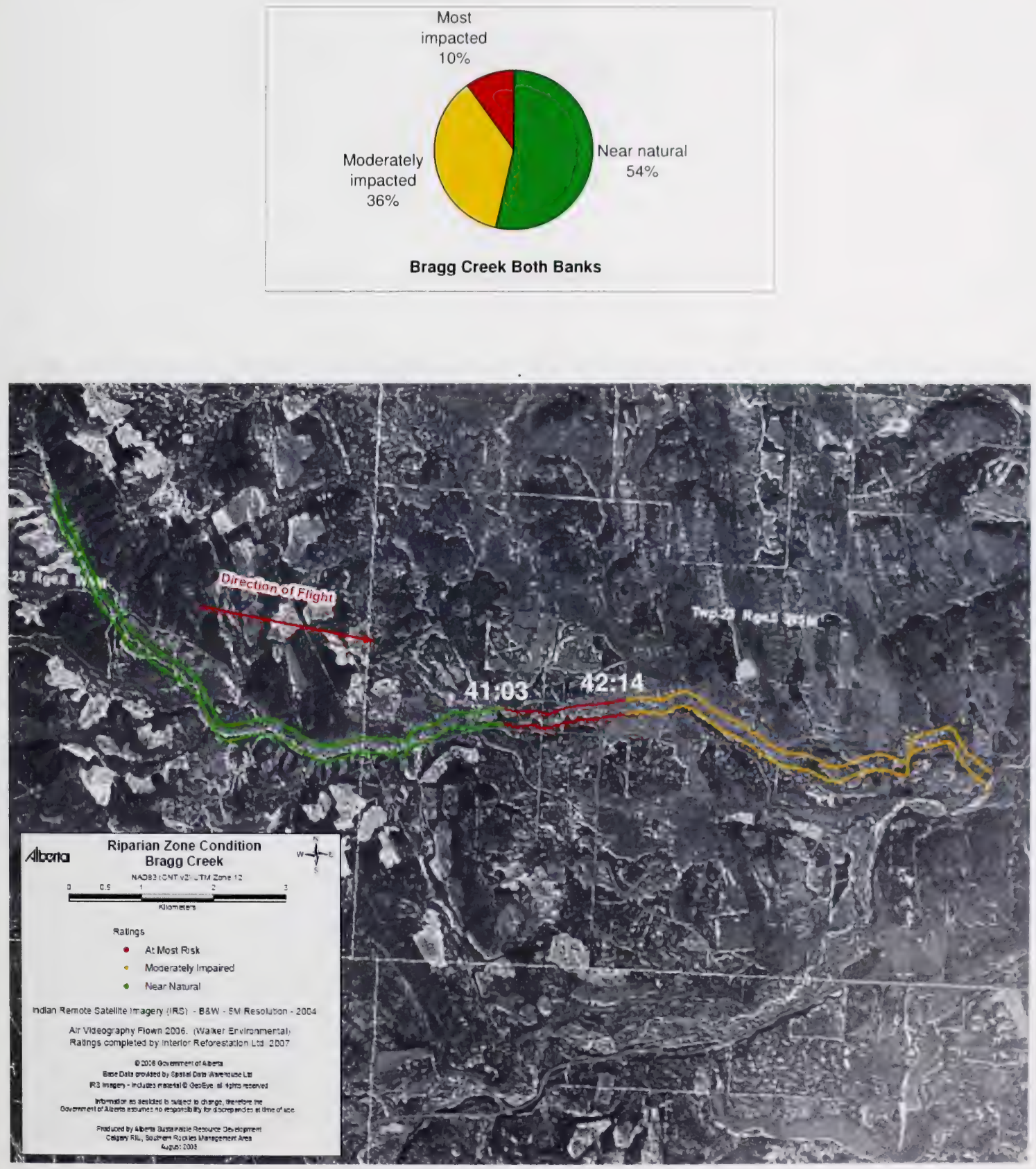


\section{Fisher Creek}

Reach Flown: From near its headwaters in the northwest part of Twp 22, Rge 4, W5M to its confluence with Threepoint Creek.
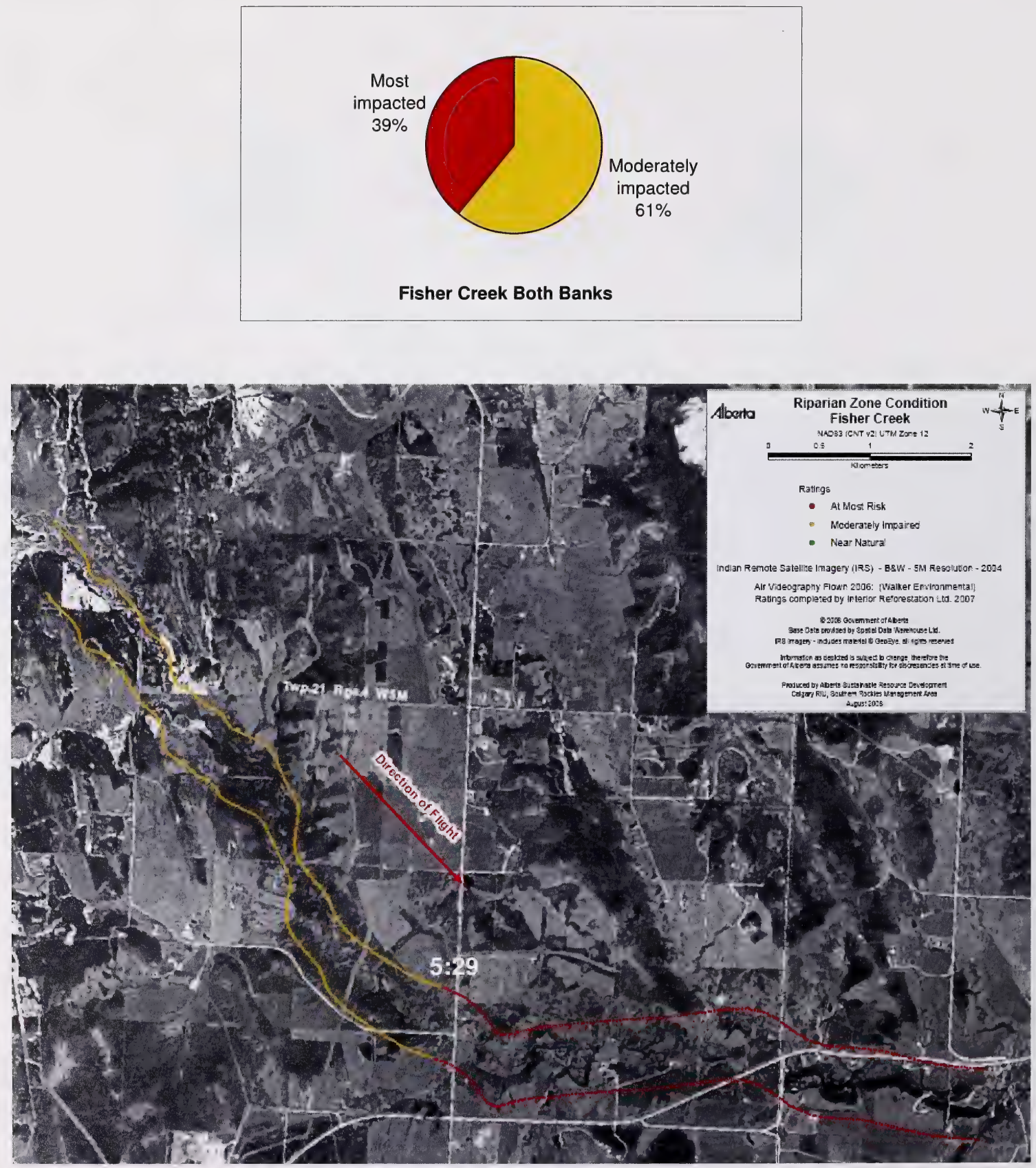


\section{Ware Creek}

Reach Flown: From its confluence with Three Point Creek to the western part of Twp 20, Rge 4, W5M.

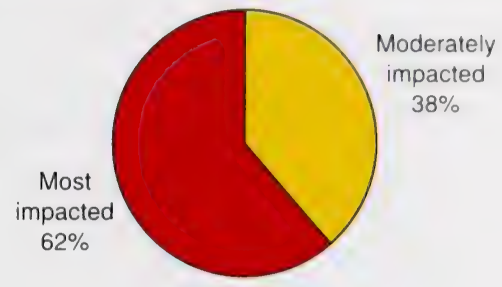

Ware Creek Both Banks

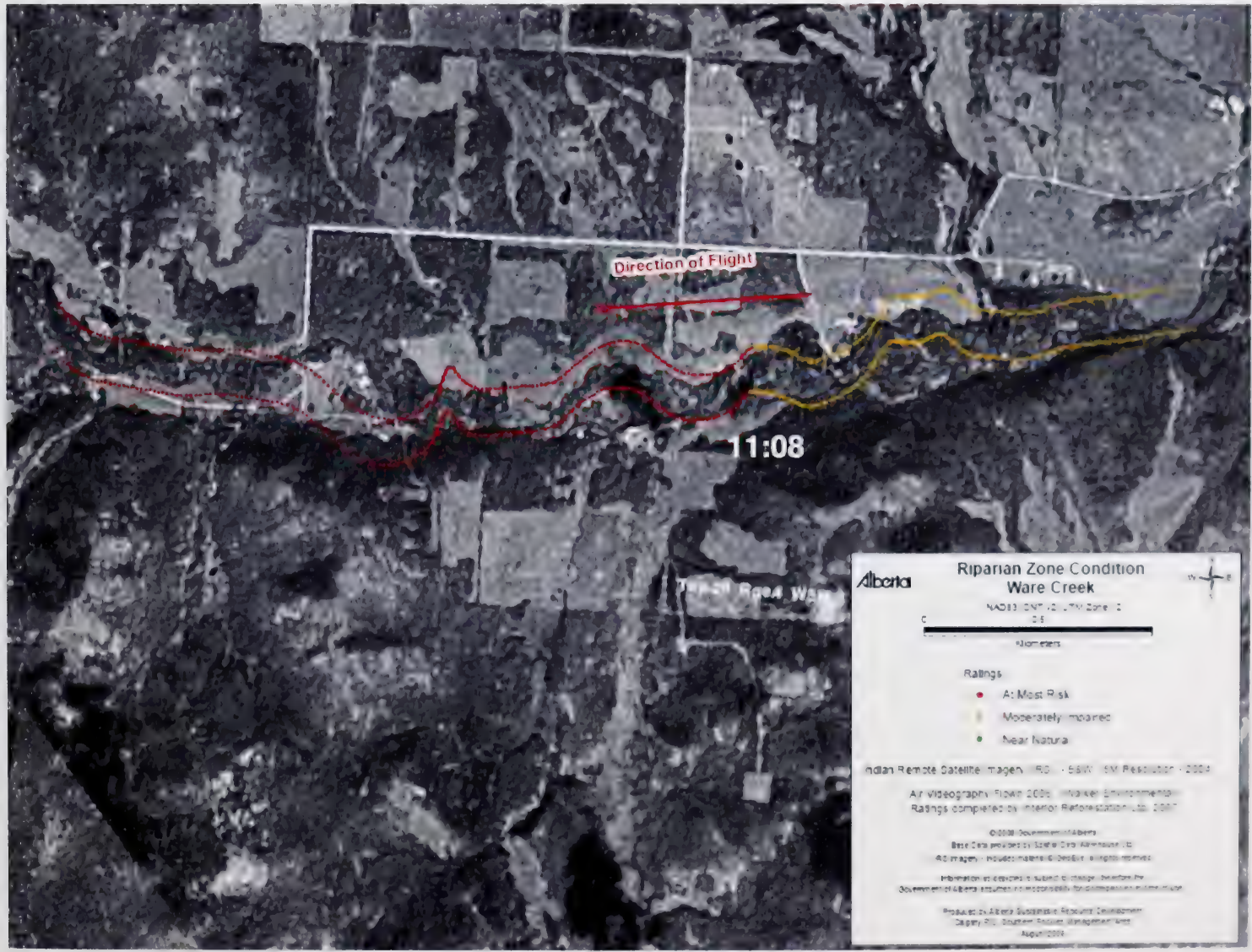




\section{Bow River - Section C, Right Bank}

Reach Flown: From near its crossing at the Calgary city limit to its confluence with the Highwood River.
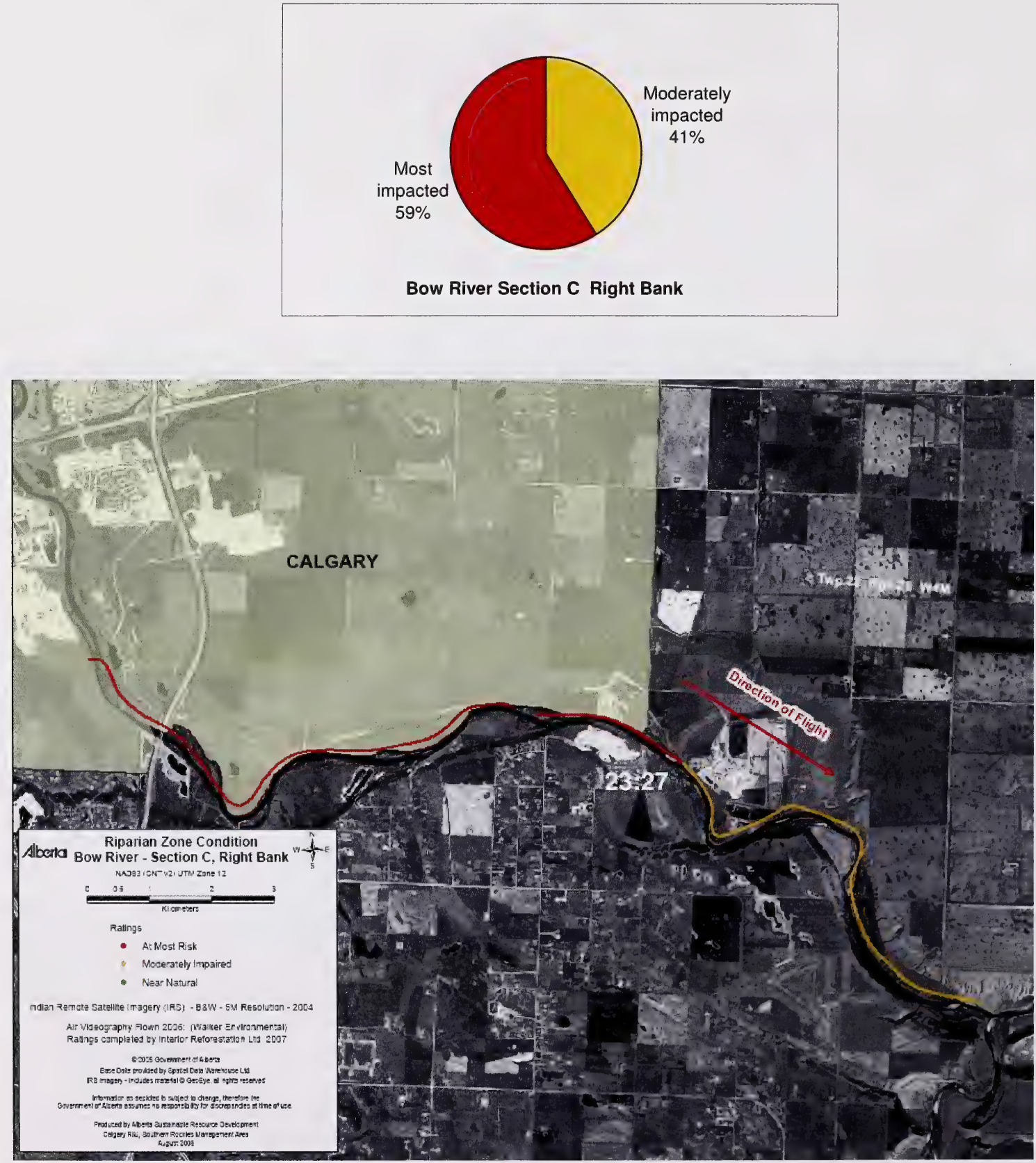


\section{Bow River - Section C, Left Bank}

Reach Flown: From its confluence with the Highwood River to near its crossing at the Calgary city limit.

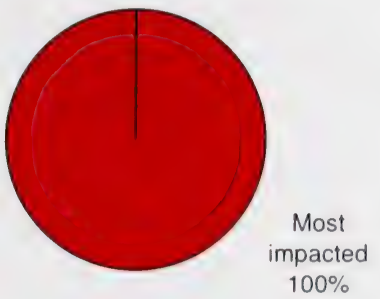

Bow River Section C Left Bank

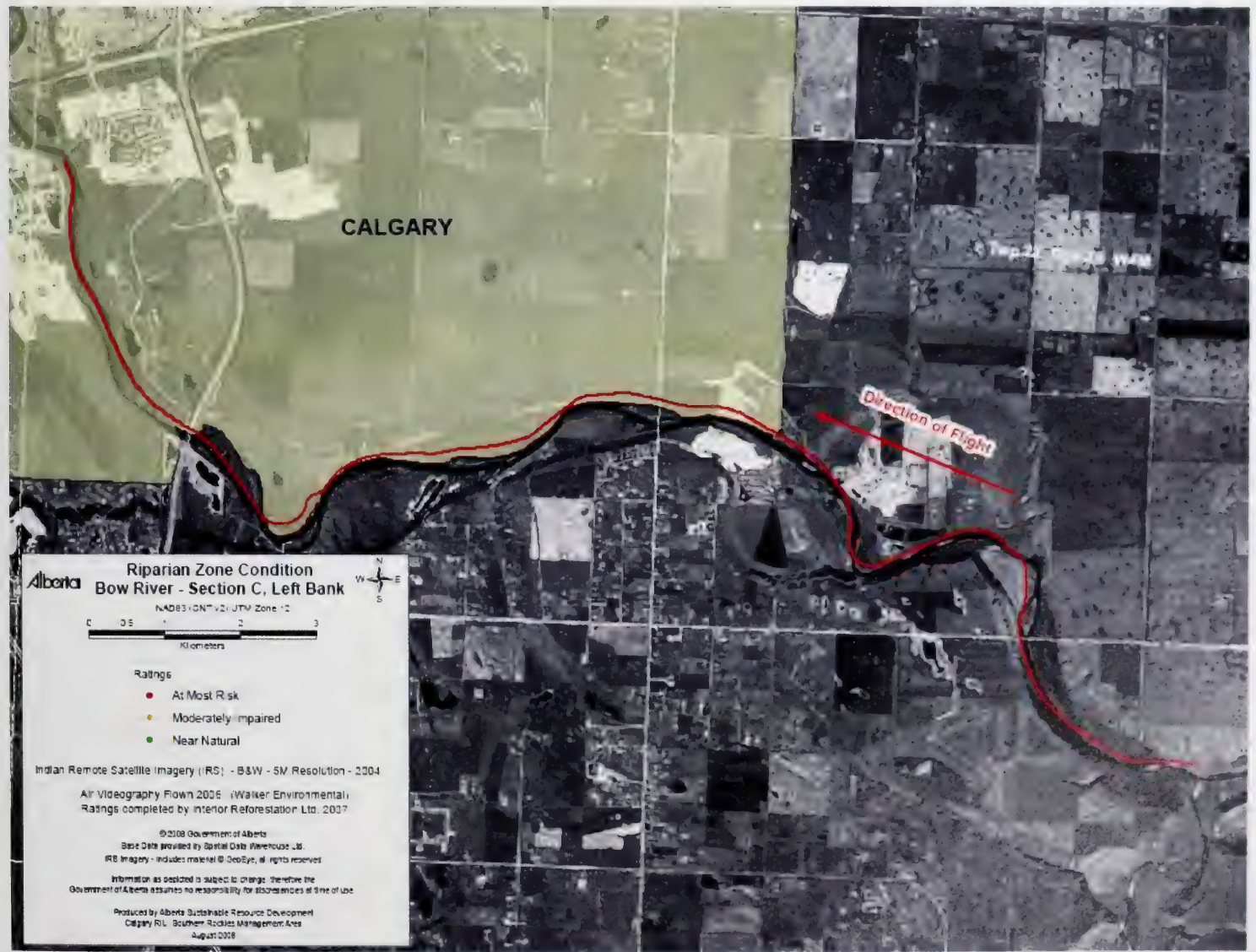




\section{Summary of Independent Evaluation of Methodology}

An evaluation of the video imagery and riparian scoring method was carried out independently from this project. The evaluation contained the following general observations:

- Conventional aerial photography is suggested for riparian classification because of its ability to show the limits of riparian areas with minimal obstruction.

- A modified version of the current Grassland Vegetation Inventory classification, which includes a riparian modifier, is recommended for classification instead of the "tree-shrub" and "grass-shrub" classification that was used in this study.

- Videography has application in rating the seven criteria that make up the final classification of riparian condition in areas where there is minimal cover of woody vegetation (e.g., trees and shrubs) or where stream channels are wide enough to see sideways into tree and shrub stands. High resolution conventional aerial photography can be used for stream reaches flowing through grasslands or parkland areas where there is minimal cover of woody species to obstruct the ground. In areas of dense tree or shrubs cover especially in upper reaches where channels are narrow, ground checking is the best means of rating the seven criteria.

The evaluation also included the following detailed comments:

- Increase the video's resolution so that it is possible to distinguish the species of shorter shrubs.

- Include as part of the classification of riparian condition an assessment on the extent and condition of shrub species such as willows which when abundant in a riparian area indicates pristine or almost pristine condition.

- In addition to a continuous video, the system could also provide overlapping georeferenced high resolution still frames, which can be easily zoomed into to see features in more detail.

Appendix 2 contains the complete evaluation.

Members of the Elbow River Watershed partnership reviewed the videos of Elbow River and Bragg Creek and provided comments. Suggestions included factoring in the condition of the flood area, and reducing the score in areas where people have used rock armouring to stabilize the riverbank.

Commercially-available technologies were also investigated as part of this project. These included a multi-camera product called RouteMapper, used by IBI Group in Edmonton, Alberta, and geo-referenced spherical video technology, developed by Immersive Media Corp. These technologies offer higher resolution and wider viewing fields than the method used in this study, but at a much higher cost.

\section{Conclusions and Recommendations}

In this study, aerial videography provided a relatively rapid, low-cost way of permanently recording land-use and environmental conditions on the narrow strips of land that make up riparian areas. The imagery collected can be viewed in its raw form on DVDs or used for future projects. Geo-referencing of videos makes it possible to view 
and map results in a GIS, and add any number of overlays such as feature layers. Unlike ground-based scoring methods that collect data at discrete sampling points, aerial videography captures a continuous image along its path.

For future work of this kind, the highest resolution video camera available is recommended. Helicopter speed, especially around sharp bends in the stream, should be kept to a minimum to help conserve ground details on the imagery. Ground checking is recommended to increase the accuracy of scoring, especially in areas where dense tree cover obscures visibility. Other factors to consider include the size of the study area, where the flying range of a helicopter may be exceeded. The availability of experienced videographers may also be an important consideration. Newer technologies are now available to enable automated geo-referencing of video images, and provide a range of post-flight processing and viewing options. For example, spatial multimedia applications are interactive and display video along with a moving cursor over a digital map.

Finally, a comparison of results from this project with ground-based studies should be made before undertaking more aerial videography work in southern Alberta. Appendix 2 contains additional recommendations.

\section{Project Cost Summary}

Alberta Environment's Monitoring Management Team of the Environmental Assurance Branch provided funding for this study. The mission of the team is to ensure optimal value in return for resources allocated to monitoring programs and projects. This includes supporting all areas of the department's monitoring activities with a view to continuous improvement and establishment of partnerships for collecting, analyzing, and communicating information.

\section{Cost Breakdown}

Staff Orientation and Technical Briefings

Helicopter charter

Video-taping and post-flight processing

Classification and scoring

DVD Production

$\$ 2,000$

11,200

6,200

13,400

250

\section{Total Direct Costs}

$\$ 33,050$

Indirect costs included work such as project coordination, GIS, mapping, and technical evaluation, which were done using in-house staff and resources. 


\section{References}

Fitch, L., B.W. Adams and G. Hale, Eds. 2001. Riparian Health Assessment for Streams and Small Rivers - Field Workbook. Lethbridge, Alberta: Cows and Fish Program. (adapted from Riparian and Wetland Research Program, School of Forestry. 2001. Lotic health assessments: Riparian Health Assessment for Streams and Small Rivers [Survey] User Guide. University of Montana, Missoula, Montana, USA. January 2001.) 75 p.

Mills, B. and Scrimgeour, G. 2004. The Effectiveness of Aerial Videography to Characterize Lakeshore Condition. Data Report (D-2005-017) produced by Alberta Conservation Association, Location, Alberta, Canada. 52 pp. + App. 


\section{Appendix 1 Scoring Method}

Efforts were made to develop a method for assessing riparian condition that was consistent with other methods already in use, including ground-based methods used by Cows and Fish (Fitch et al. 2001) and a lakeshore application used by Alberta Conservation Association (Mills and Scrimgeour 2004). Key elements of these methods were adopted and modified to suit the particular characteristics of using aerial videography along watercourses. Meetings with representatives from Cows and Fish and the Alberta Conservation Association were held early in the process to determine how best to ensure consistency with existing methods.

Two riparian vegetation cover-types were chosen as reference conditions for scoring floodplains within stream reaches: grass-shrub and tree-shrub. Some remnant natural vegetation had to be present to categorize an area within breaks. The detailed descriptions are as follows:

1. Grass-shrub: Natural, reference condition was determined to be grass-shrub for small rivers or streams located in the Grassland Natural Region, and where there was no visual evidence of human impacts and the vegetation displayed good health. The riparian area may have supported trees prior to or early in post-settlement time. However, the reach appears to have lost the ability to experience tree recruitment because of the heavily grassed shoreline and low gradient stream. Also, there was no evidence on the floodplains to indicate that they were wooded in recent times. Low gradient streams with dense grass vegetation to the waters edge do not have the scouring power even in peak spring flows to create recruitment sites which are bare, moist, low elevation bars or beaches, which trees need for seedling establishment. A few, forested floodplains within rural/farm settings occurred in the grass-shrub classification, but they occupied a small percentage of the overall area and consequently did not affect the overall classification.

2. Tree-shrub: Natural, reference condition was determined to be tree-shrub where remnant trees or healthy stands of trees were a recurring feature within the riparian area, and coincided with the Parkland, Foothills and Rocky Mountains Natural Region.

\section{Scoring}

The scoring criteria for each of the individual attributes for the grass-shrub cover-type were as follows:

1. Natural vegetation: $>95 \%=40,75-95 \%=25,33-74 \%=10,<33 \%=0$

For example, if the natural vegetative cover was greater than $95 \%$ of the area within a break, it was scored as being natural (score of 40). Grass-shrub cover was scored as 'natural' based on the degree of grazing. Natural species could not be identified in the film but if the vegetative cover of grasses was long and did not appear to have been grazed that season it would be scored as natural. The degree of grazing, and the size of the area impacted by the grazing, would be scored accordingly. As severity of grazing increased, the score for 'natural vegetation' decreased. For example, heavily grazed areas, including the banks, which accounted for more than $33 \%$ of the area within the break would have a 0 score. 
2. Plowed or human-caused bare ground: $<5 \%=15,5-15 \%=8,16-25 \%=4,>25 \%=0$ Human-caused bare ground also included bare ground resulting from cattle impacts, dirt roads, and trails. The scores are based on the amount of floodplain area within a break that has been disturbed.

3. Bank armouring or channelized: $<5 \%=10,5-15 \%=6,16-25 \%=3,>25 \%=0$

Area within a break that is impacted by bank armouring and/or channelization is scored accordingly. Less than $5 \%$ of the break area had to be free of armouring or channelization to receive a score of 10 .

4. Bank stability (human activity): $<5 \%=15,5-35 \%=8,>35 \%=0$

Scoring for this attribute looked at the loss in bank stability from human activity such as clearing, and included grazing impact to bank stability that occurred within a break area. When a break area had armoured banks, the bank was considered stable, and the bank armouring category picked up the extent of that armouring.

5. Flood water access: $>95 \%=10,35-95 \%=5,<35 \%=0$

Flood water access was scored based on the amount of bank armouring and berms visible within a break area that would reduce or eliminate flood water access to the floodplain. Deeply incised channels also reduce flood water access to the floodplain, and attempts were made to score areas accordingly. However, down-cutting was very difficult to see on the film, and this may have resulted in scoring errors. Ground checking or local knowledge of the stream reach could be used to increase the confidence level for this scoring category.

6. Development: $<5 \%=10,5-33 \%=5,>33 \%=0$

Development included hard-surfaces like roads, parking areas, and structures. These were scored on the area taken away from the floodplain within the break area. Trails and roads that were not paved were included in the 'plowed or human-caused bare ground' category.

Once the individual scores were tallied, the breaks were classified as follows:

- $\quad$ Near natural condition (score of 81-100): means that human disturbances and alterations relative to the seven parameters selected for this study appear to be minimal, and vegetation appears to be healthy and in natural condition.

- Moderately impacted (score of 51-80): means that some signs of stress are clearly apparent relative to the seven parameters selected for this study. The reach may be more vulnerable to erosion, and be less capable of rebounding from floods and human impact. There is some alteration to natural vegetation.

- Most impacted (score of 0-50): means that human impacts relative to the seven parameters selected for this study are prevalent. The likelihood that the stability of the riparian area has been severely compromised is high. Alteration to natural vegetation is extensive. 
The scoring criteria for each of the individual attributes for the tree-shrub cover-type were as follows:

1. Natural vegetation: $>95 \%=40,75-95 \%=25,33-74 \%=10,<33 \%=0$

To score total points, the floodplain natural vegetation cover would have a tree cover with good density of understory for $95 \%$ of the floodplain area within the break area. When the understory of woody vegetation had been lost and replaced with grasses, the floodplain was no longer at a '40' score. The percentage of woody understory and trees remaining affected the score. For example, no understory but mature tree cover would still offer some stability to the floodplain and would not score as low as an area with no tree cover left.

2. Observable recruitment of tree species: Yes $=5$ No $=0$

A break area with a large range in tree ages was scored 'Yes' for recruitment as it demonstrated on-going recruitment to allow for multiple age groups. Floodplains with only mature trees have not had recruitment for a long time and would score 'No' for recruitment. Not all areas had to have recruitment to score a 'Yes $=5$ '. For example, if the majority of floodplains $(90 \%)$ had recruitment, the break area was scored ' 5 '. The reverse was used when an area had the majority $(90 \%)$ of the floodplain with no recruitment; the break area was scored ' 0 '.

3. Plowed or human-caused bare ground: $<5 \%=10,5-15 \%=6,16-25 \%=3,>25 \%=0$ Human-caused bare ground also included bare ground resulting from cattle impact and dirt roads and trails. The scores were based on the amount of floodplain area within a break that has been disturbed. The scoring scale $(<5 \%=10)$, is 5 points lower than for the grass-shrub category $(<5 \%=15)$ to accommodate the extra category of observable recruitment.

The scoring criteria for bank armouring, bank stability, flood water access, and development were the same as the grass-shrub cover-type. If any one attribute, with the exception of "observable recruitment of tree species", was scored at "maximum level of impact", then the classification was determined to be at least "moderately impacted" or "most impacted", depending on the total score. Once the total score of each break was tallied, riparian condition was classified in the same way as the grass-shrub covertype: near natural condition (score of 81-100); moderately impacted (score of 51-80); most impacted (score of 0-50).

\section{Video Assessment Criteria}

Breaks: The method for determining the locations of breaks generally consisted of stratifying out natural or near natural areas, town sites, and heavily impacted areas unless the areas were too small. Typically, reaches that had wider valley bottoms or flood plains were separated from reaches having high, steep banks.

Time stamps for breaks were recorded when the new break area covered the viewing screen to the bottom right-hand corner or the bottom of the screen if it did not pass through the bottom corner. The end time stamp was recorded just before the break area was about to go off screen (the bottom of the viewing screen). This resulted in time breaks with 0:01 time differences, for example 0:06:23 end time, 0:06:24 start 
time for the new area. Streams entering, and other attributes noted with a time stamp, used the same criteria. Thus, when a stream entered the creek or river the recorded time was when the attribute was in or near the bottom right-hand corner.

The attribute spreadsheet has four bank stability ratings. The first two are self explanatory, 'natural stable' and 'natural eroding' refers to banks that are naturally stable or eroding depending where they occur along the river. River channels are dynamic, with depositing (stable) and eroding banks. This is how the stream moves across the floodplain and is part of the natural mechanism for floodplain turnover rate (how quickly the channel moves from side to side within the floodplain). The 'human altered/destabilized' column was checked if the site had been cleared, heavily grazed or a high percentage of natural vegetation lost. It may not be slumping or eroding at the present time but it is a weak point (unstable) during flood events. The 'human altered/armoured' column was checked if the site was channelized and/or armoured.

To simplify data presentation, we used selective abbreviation that should be apparent as you read through the comments column.

- Sometimes the riparian or floodplain area was referred to in two parts: 1) the 'riparian area' which referred to the floodplain closest to the stream and 2) the 'floodplain' or '1-200 year floodplain', referring to the floodplain furthest from the stream. These two terms were used together when different vegetation or activities occurred on the floodplain at a specific time frame during the film. For example, the riparian area vegetation has a tree cover with a dense understory while the floodplain behind has been cleared and grazed.

- Floodplain is used as a general term for both areas when no distinction is needed between the two, for example, the floodplain has farm buildings and vegetation is cleared to the rivers edge with heavy grazing impact.

- When referring to 'vegetation' on the floodplain, it was implied that 'vegetation' is the natural vegetation, i.e. vegetation cleared to waters edge = natural vegetation has been cleared from the tree-shrub group and grass and herbaceous plants have replaced it.

- When vegetation cover is referenced with a tree-shrub or a shrub/tree designation, which ever had the highest density was listed first. If more than two, they are presented in decreasing order of density with the highest listed first. For example grass-shrub/tree would mean that the majority of vegetation cover is grass, then shrubs, with the lowest density as trees. 


\section{Appendix 2 \\ Summary of Independent Evaluation of Results}

The following summary was provided by Ed Karpuk, Resource Inventory Specialist with Alberta Sustainable Resource Development. Mr. Karpuk has more than 25 years of experience working with aerial imagery and conducting biophysical inventories and physical land classifications, and has authored numerous reports and publications on these topics.

\section{Assessment of Interior Reforestation Co. Ltd's Riparian Zone Classification of Todd Creek}

1. The reason for distinguishing one reach from the other on the basis of riparian health is not clear and in fact some the reaches classified are much too long and should have been split out more.

2. After reviewing the riparian health assessment of the entire reach of Todd Creek, it is quite evident that using oblique videography for classification is not nearly as effective and accurate as the tried and true aerial photography delineated using a stereoscope; verbal descriptions of where features are on the ground are difficult to pin-point; the best is a delineation around a particular feature or a point that is annotated.

3. I question the purpose of attempting to determine whether vegetation cover in certain stretches were formerly Forest/Shrub or Grassland/Shrub; suggest classifying the plant communities as you see them and not be concerned what the original plant covers were; also use the GVI Lotic Site Types and Anthropogenic Site Types with a Riparian Zone modifier. Unless one has older aerial photography to determine what the original physiognomic vegetation communities were it is somewhat presumptuous to assume what the communities were based on what is observed currently.

4. Need to have the videos geo-referenced so that one can point to a specific feature on the image and get the exact coordinate.

5. Also the videos should have the capability of pointing to and annotating a feature and having the pointer and annotation anchored to the feature as the video rolls by.

6. An oblique video taken during an event like a flood or during specific periods would be most useful for assessing condition and picking out interesting features in a timely fashion.

7. Maybe instead of a video have overlapping geo-referenced still frames of high resolution parts of which can be zoomed into to see certain features in more detail. 
8. It is very difficult in a video to show the entire riparian zone because of altitude and flight pattern even of a highly maneuverable aircraft like a helicopter. High resolution vertical air photo imagery most easily shows a riparian zone and is the best medium for riparian mapping and classification.

9. Narration associated with a video in most cases is not necessary and is often subjective because in some cases in may be difficult on the spur of the moment for most people to make relevant, useful statements.

10. Trying to determine location from a non-geo-referenced video is usually difficult and time-consuming.

11. These videos should have something in the view screen while it is playing that indicates what reach is being flown.

12. Also it would be nice to have a direction of view indicated in the video screen and a small interactive map that shows the helicopter traveling along a path.

13. More identification of fence line contrasts and use these to start or end reaches.

14. Any point to separating out and classifying one side of the stream versus the other; could not both sides be combined and classified together?

15. Classification should have identified ranches, farms, and country residential which back onto the creeks.

16. Latter parts of Todd Creek were overrated as impacted and should have been classified as more Near Natural rather than Moderately Impacted.

17. Small areas of dense riparian forest should have been identified.

\section{General Comments on the Todd Creek 2006 Aerial Videos}

a) Flight upstream north from mouth of Todd Creek where it enters the Oldman River Reservoir then to NW to its headwaters; camera direction of view has the river to the right and for the flight line heading north the view it $\mathrm{N}$ to $\mathrm{NE}$; at around the 15 minute mark the view changes to $\mathrm{N}$ to $\mathrm{NW}$.

b) Video starts at $~ 4: 24: 08$ minutes so we do not see the start at the Oldman River Reservoir and around a 1.5 mi stretch of Todd Creek north of the Reservoir.

c) Lower stretch of the Creek has very little tree or shrub vegetation obscuring the valley and creek channel; one is able to determine water turbidity and depth from colour: 
d) very good video which can be paused to show areas of extensive cattle grazing, stream crossings by cattle and vehicles,

e) very good side views to distinguish the species of trees and tall shrubs and their vigor; not enough resolution to distinguish shorter shrubs; nor can one pause the video to a still frame and zone in on features for a more detailed view;

f) good views of fenced-off riparian areas which are in good to excellent condition;

g) variations in green tone for the most part help to distinguish the riparian zone from uplands, however, vertical colour infrared aerial photography viewed in 3D either using a conventional stereoscope or in softcopy on a computer would be best for delineating the extent of a riparian zone;

h) not readily easy to pin-point the exact location of a notable feature visible in a still frame for further investigation on the ground; pdfs of the reach maps are not detailed enough and what would be required is the shapefile of the time stamped flight paths overlaid on orthoimagery (e.g. Valtus true colour, available panchromatic or CIR) and locate the exact site by feature comparison;

i) it would be useful to have a direction of view arrow pointing in the direction of view that shifts with the camera angle; also an interactive map on the side which shows the exact position of the camera relative to the Creek.

j) in a number of instances the entire width of the riparian zone was not caught on film

k) Narrative in most cases is does not provide useful information except for possibly comments on condition of range and height of grass; not easy to distinguish height and density of forbs and grasses from videos because of resolution restriction;

I) Would have been useful in the narrative to identify Road (Twp or Rge road) and Highway numbers, names of water bodies, confluences with other streams to help with pinpointing location (e.g. roads visible in 13:10.03, 18:56.16; confluence with small stream 23:28.21); narrator does correctly acknowledge Hwy 22 crossing Todd Creek in 25:13.01 and Willow Valley Road in 34:51.13. Also mentions confluence with Elk Creek at around 40:38.00 and Willow Valley school 41:03.01.

m)Some excellent fence line contrasts (e.g. 9:47.02, 11:35.12; 23:13.26)

n) Large feedlot visible to the left very close to Todd Creek in 14:28.29 and the range condition in the location is very poor;

o) Lots of comments regarding the amount and condition of grass but nothing mentioned about the condition and cover of indicator shrubs like tall willow 
which in abundance in a riparian zone indicates pristine condition.

p) Good acknowledgement of entering the Foothills in around 27:00.00

q) Todd Creek channel becomes more obscured by dense woody growth mostly poplar trees starting at around 28:00.00.

r) Start of stream bank fencing project in 35:13.19 which ends around 39:00.00; also some fenced off sections further upstream.

s) In this stretch the lack or occurrence of willow is a definite indicator of riparian health.

t) White spruce noticeably starts becoming more dominant from poplar in frame $45: 39.17$.

u) Very difficult to pick out the Creek under the dense deciduous and coniferous tree canopy after around 46:00. 
NOTES: 

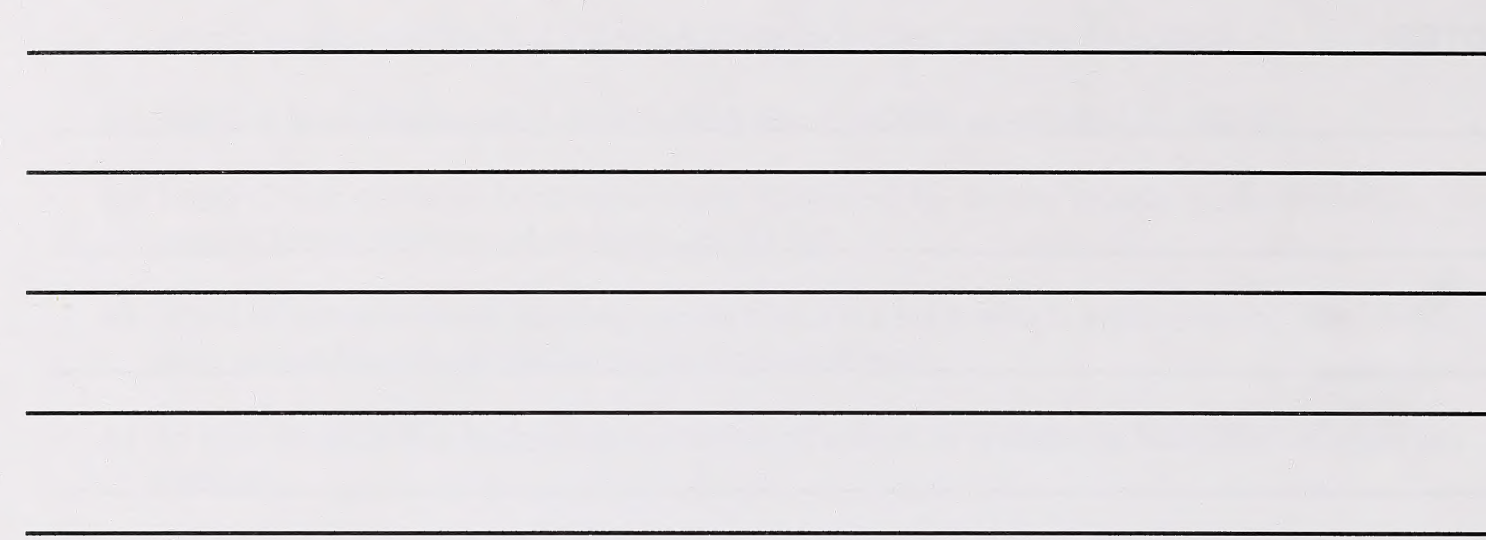


\section{Appendix 3}

\section{DVDs}

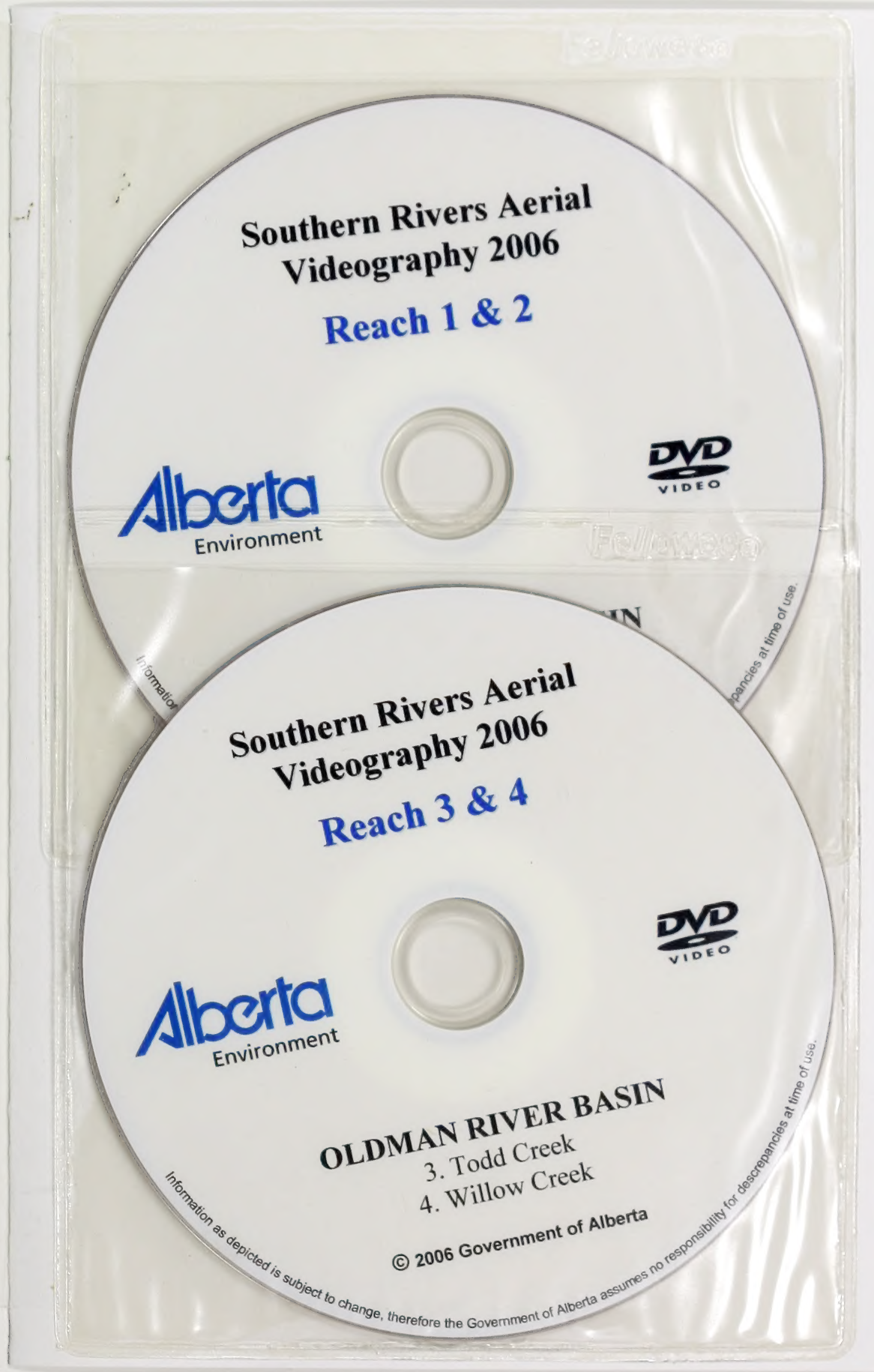


IIIT) 